IZA DP No. 6251

Warrant Economics, Call-Put Policy Options and the Fallacies of Economic Theory

John Hatgioannides

Marika Karanassou

December 2011 


\title{
Warrant Economics, Call-Put Policy Options and the Fallacies of Economic Theory
}

\author{
John Hatgioannides \\ Cass Business School, City University London \\ Marika Karanassou \\ Queen Mary, University of London \\ and IZA
}

Discussion Paper No. 6251

December 2011

\author{
IZA \\ P.O. Box 7240 \\ 53072 Bonn \\ Germany \\ Phone: +49-228-3894-0 \\ Fax: +49-228-3894-180 \\ E-mail: iza@iza.org
}

\begin{abstract}
Any opinions expressed here are those of the author(s) and not those of IZA. Research published in this series may include views on policy, but the institute itself takes no institutional policy positions.

The Institute for the Study of Labor (IZA) in Bonn is a local and virtual international research center and a place of communication between science, politics and business. IZA is an independent nonprofit organization supported by Deutsche Post Foundation. The center is associated with the University of Bonn and offers a stimulating research environment through its international network, workshops and conferences, data service, project support, research visits and doctoral program. IZA engages in (i) original and internationally competitive research in all fields of labor economics, (ii) development of policy concepts, and (iii) dissemination of research results and concepts to the interested public.
\end{abstract}

IZA Discussion Papers often represent preliminary work and are circulated to encourage discussion. Citation of such a paper should account for its provisional character. A revised version may be available directly from the author. 
IZA Discussion Paper No. 6251

December 2011

\section{ABSTRACT \\ Warrant Economics, Call-Put Policy Options and the Fallacies of Economic Theory}

In this paper we aim to trace the roots of the ongoing economic mayhem and to unmask the chorus of the tragedy which plays on the world stage. The main thesis of our work is that, despite the triumphant rhetoric praising the merits of perfect competition, the global fields of the dysfunctional market system have mushroomed in what we call Warrant Economics for the Free-Market Aristocracy. Warrant Economics unfolds in two symbiotic tenets that constitute the subtle architecture of the neoliberal edifice: (i) the systemic creation and preservation of inequality via Call-Put policy options, and (ii) the systemic exploitation of inequality via novel and toxic forms of securitisation. In effect, the power structure of insiders' capitalism that we describe, trough the costless appropriation of an intricate cobweb of CallPut structures, has distorted competition and accelerated economic concentration. We view the income distribution effect, which favours the top 1\%, and the business concentration effect, which gravitates competition towards oligopolistic/monopolistic industries, as the two sides of the Warrant Economics coin. We argue that the Warrant Economics state of capitalism has been legitimised by a degenerating research programme blossomed under the fallacy that economics is the "physics of society". In this faculty of thought, we perceive the Great Recession as a symptom of Warrant Economics, rather than as a tsunami-like event.

JEL Classification: E66, G01, G10

Keywords: Warrant Economics, Call-Put policy options, securitisation, monopoly, income distribution, Great Recession, sovereign debt

Corresponding author:

Marika Karanassou

School of Economics and Finance

Queen Mary, University of London

Mile End Road

London E1 4NS

United Kingdom

E-mail: m.karanassou@qmul.ac.uk 


\section{Introduction}

Is it another long-lasting nightmare? Did noble dreams of prosperity for all, insulated we were vehemently told from boom to bust cycles, unexpectedly crash landed? How is it ever possible that the vessel of the "miracle economy" with the "dream team" of skippers at its helm delivered such a frightening cargo, the Great Recession? Forensic examination carried out during the apocalyptic 2007-present period has identified the following interwoven features of our turbulent epoche.

First, Globalisation, the high promise - bitter disappointment enterprise. This political and economic mega trend of the past three decades, nourished by FIAT money and through the dominance of the US dollar as the international reserve currency, has resulted in global imbalances with persistent surplus and deficit countries. The legitimate reaction of South East Asian sovereigns to the barbarous and humiliating IMF policies, in the opinion of many, during the 1997 Asian crisis made reserve accumulation (mainly in the form of US Treasury Bills) an insurance against the flight of hot currency from their opened-up dominions. Crucially, the market based gradual structural reforms that started in the late 1970s, have transformed China in the new millennium to a global superpower and the world's largest creditor (the mercantilist approach for the parity of the renminbi against the US dollar is instrumental to the cause). The massive reserve hoarding by the Asian nations triggered an industry of reserve recycling by the US Fed and other central bankers enabling them to run cheap FIAT money policies and fuel an unsustainable asset and consumption boom. ${ }^{1}$

Second, the escalating deregulation of financial services/capital markets orchestrated by central bankers, regulators and neoliberal political administrations guided by the 'Maestro', the 'Oracle', aka Mr. Alan Greenspan.

Third, the unregulated proliferation of toxic and opaque synthetic assets, wrapped up in shining gloss, by the sect of gung-ho bankers operating in ghettos of greed and overleverage. Such financial structures were (i) poorly understood by their widespread recipients, (ii) implausibly highly rated by the cartel of rating agencies, and (iii) incompetently risk managed by their creators.

True may be, but such utterance offers only a light touch explanation for the deeper causes of the post-2007 subprime blues, the financial meltdown after the collapse of Lehman Brothers in September 2008 and the unfolding of the worst economic crisis since

\footnotetext{
${ }^{1}$ Under a Gold standard, reserve accumulation in gold rather than US Treasuries (e.g. by China, equivalent to more than 2.5 trillion dollars in US T-bill issuances) would have been deflationary, since it would drain the world of liquidity and force the US Fed to raise interest rates. In contrast, under FIAT, the US dollar has been hotter and hotter in the pumps of printing ever since the 1970s. The currency component of M1 was increasing by around 6 billion per annum during the $1970 \mathrm{~s}, 11.8$ in the $1980 \mathrm{~s}, 30.1$ in the $1990 \mathrm{~s}, 33.7$ in the $2000 \mathrm{~s}$, and 58.3 from $1 / 2010$ to $1 / 2011$. See the Federal Reserve Bank of St. Louis' graph of the currency component of M1 (CURRSL) at http://research.stlouisfed.org/fred2/graph/?s[1][id]=CURRSL\#
} 
the 1930s. Four years on and questions are still looming large. What is the efficacy of the Armageddon of bailout plans instigated by policy makers (and predominantly funded by the taxpayer) to rescue at any cost financial institutions deemed as 'too big to fail'? Who are the main beneficiaries of the unorthodox monetary policies such as quantitative easing (i.e. printing of fiat money to twist the yield curve)? The fragile recovery of 2009/10 and the massive profits of banks and big corporations offered a scintilla of hope that the unprecedented fiscal and monetary interventions could put the global economy back on a sustainable growth path. Banks were expected to honour their side of the deal; the society had bailed them out and, in turn, they were presumed to bail out the economy through lending. This early euphoria though was premature. Growth in the western developed economies is proving more anaemic than it was originally thought, and unemployment is high and persistent; banks are hoarding profits, and lending to households and small- and medium-sized enterprises (SMEs) is drying up once more, or is available under punitive interest rates; and big corporations are piling up cash instead of engaging in productive investments.

In 2011, the private sector crisis is transformed into a public sector crisis. Under the pretence of short-term fiscal consolidation, many indebted western sovereigns are introducing self-defeating draconian austerity programmes (unless one believes in the effectiveness of an "expansionary fiscal contraction", quite an oxymoron). Such an agenda is (i) preemptively instigated in the UK, and to a lesser extent in France, guided by ideological conviction to preserve the elusive AAA rating, (ii) aiming to pacify the threat, made by the opportunistic and amorphous mass of bond vigilantes for a private market credit shutdown in Spain and Italy, and (iii) a brutal necessity, reminiscent of East Asia in 1997, demanded by the troika (EU/ECB/IMF) in exchange of direct loans to the eurozone peripheral countries - Greece, Ireland, and Portugal. At the same time the balance sheets of big banks are turning up to be far more toxic than the recent stress tests made us to believe and further recapitalisation (especially for the financial institutions of the Eurozone) is needed. The banking industry seems as dysfunctional now as it was at the heights of the financial crisis in 2008. So what is going on?

In this paper we aim to trace the roots of the ongoing economic mayhem and to unmask the main chorus of the tragedy which currently plays on the world stage. This is neither an act of schadenfreude nor an attempt to stockpile facts and arguments for radical advocacy. Rather, it is an endeavour to unravel the riddles of the current economic predicaments nourished by a powerful consensus in economics and finance. An academic orthodoxy which, with unparalleled effrontery, compiled a system of non falsifiable "theories" and trumpeted it as immortal wisdom.

Prominent examples are the general equilibrium (GE) theory (and its recent incarnation of dynamic stochastic general equilibrium models) together with the first and second 
welfare theorems, the efficient market hypothesis, the natural rate of unemployment, all distinct yet inextricably related dogmas marketing an aura of rigour and unquestionable scientific purpose. ${ }^{2}$ Since the 1960 s, the dominant paradigm that rules the roost of economics and (since the early 1980s) economic policy itself, asserts with doctrinaire conviction that unrealistic microeconomic foundations should dictate macroeconomics and finance. Elegant axiomatic mathematical modelling of the self-regarding behaviour of a representative, rational and eternally utility - an overloaded term that enshrouds motives, behaviour and wellbeing - profit maximising economic agent, void of any cognitive limitations, draws the only possible and acceptable magna carta of legitimate economic theorising (satisfying the self-referential criteria of the academic status quo).

Such faculty of thought, grounded upon a fictitious organism, nullifies the organic complexity of the economic social frame and the plasticity of the brain of its participants. In what follows, we reflect upon this ludicrous epistemology, which has become the lex naturalis of economic science. ${ }^{3}$

The main thesis of our work is that despite the triumphant rhetoric praising the merits of competition and unfettered capitalism, the global fields of the twisted laissezfaire economics have mushroomed in what we call Warrant Economics for the Free-Market Aristocracy. Warrant Economics stands as a synopsis of the regressive state of capitalism and the degenerating consensus of economic enquiry. In this vein, the Great Recession should be understood as a symptom rather than as an unpredictable statistical rarity that professional elites are preaching.

Warrant Economics puts into oblivion the classical marginal productivity theory, according to which, the distribution of income and wealth (excluding rentier income from intergenerational transfers of assets) mirrors an individual's incremental contribution to the value of goods and services. It breaks with the principle of a 'just reward' in a truly competitive enterprise economy, where remuneration is based predominantly upon effort, talent, entrepreneurship, innovation, and risk taking. Our analysis of Warrant Economics offers a novel and factual introspection about the formation of Power and the systemic excesses in our age of 'free-market feudalism'. In our work, we state succinctly that the income distribution effect that favours the top $1 \%$, and the business concentration effect that gravitates competition towards oligopolistic/monopolistic units of production (even for firms and industries spawned by new technologies) are the two sides of the Warrant Economics coin.

\footnotetext{
${ }^{2}$ Blaug (1992, ch. 8), under the Popperian falsification perspective, argues conclusively against the acolade "theory" and carries on to observe that "The claims that GE theory is merely making precise an economic tradition that is as old as Adam Smith, thus enabling us to show just why Pareto optimal, competitive equilibrium may never actually materialise, is a historical travesty" (p.163).

${ }^{3}$ In our thesis we abstain from ongoing developments in behavioural and evolutionary economics which, although may offer a strong claim to legitimacy, are not assimilated in the dominant economic paradigm that we peruse.
} 
Specifically, the framework of Warrant Economics illuminates the selective and distortive contractual appropriation of the residual claimancy rights stemming from the ownership and utilisation of resources and production processes. This is elaborated in Section 2 , where we expose the systemic creation, preservation and exploitation of inequality via Call-Put institutional policy options. Section 3 draws on the erroneous travails to portray economics as the physics of society. It reflects on the fallacies of the axiomatic, ultra deductive, formalist approach in economics that made the latter a utopian science. A science that is disassociated from observable reality and has been blinded by a ferocious insistence upon monolithic representations of the processes of choices and actions that human players and their institutions open up for non partisan investigation. Through the lens of Warrant Economics, Section 4 traces the key intellectual footprints in the development of the dominant economic paradigm and unwinds the segregated discourse between rhetoric and reality. It conveys an apt verdict on the devious dialectic in the neoliberal strand between a conspicuous apathy towards the real state of capitalism and the ferocious attempts to legitimize the necessity of global monopolies. Section 5 deliberates the sovereign debt crisis. It identifies a private-public-academic (PPA) partnership that is formed to ringfence the preservation of Warrant Economics in an era where the renewed problems of economic and financial instability are looming large in the world. Section 6 concludes.

\section{Warrant Economics}

During the last thirty years the political establishment, having the blessings of the dominant school of economic "theorists", originated and gradually institutionalised a profoundly inequitable, unstable and prone to systemic crisis form of market economics: the Warrant Economics for the Free-Market Aristocracy. The term Warrant is used here to denote options (i.e. rights) on a sovereign's current and, most importantly, future wealth, implicitly issued by the state itself. ${ }^{4}$

Since the roaring 1990s and up to the beginning of the current doom-laden epoch, the Washington consensus has been preaching the superiority of their policies for the social welfare under the holy trinity of low inflation, phenomenal and sustainable growth, and relatively low unemployment. Euphemisms like 'the Nice', or even bolder, 'the Fabulous Decade', 'the Great Moderation' and 'Goldilocks Economy - not too hot and not too cold, but just right', widely used since the mid 1990s, led to two concomitant developments. First, the fencing of the masterly engineered cocoon of public illusion for material prosperity for all and, second, the concealment of the destructive distributional effects of

\footnotetext{
${ }^{4}$ The textbook definition of Warrant is an option on the firm's stock issued by the firm to its managers and stockholders.
} 
Warrant Economics on the shape of the market economy. The words of the influential social analyst of the mercantilist early eighteenth century, Bernard Mandeville, echo the consequences of the twenty first century Warrant Economics: “...in a Free Nation where Slaves are not allow'd of... To make the Society happy..., it is requisite that great numbers of them should be Ignorant as well as Poor" (Mandeville, [1728]2010, p.328).

- We argue that Warrant Economics unfolds in two symbiotic tenets that constitute the subtle architecture of the neoliberal edifice: (i) the systemic creation and preservation of inequality via Call-Put policies, and (ii) the systemic exploitation of inequality via novel and toxic forms of securitisation.

An enduring concomitant aspect of Warrant Economics is the institutional allocation of power to an economic elite. This is in stark contrast to the heritage of true liberalism propagated in the work of Simons ${ }^{5}$ ([1934]1948), who pinpointed that "An important factor in existing inequality, both of income and of power, is the gigantic corporation. We may recognize, in the almost unlimited grants of powers to corporate bodies, one of the greatest sins of governments against the free-enterprise system." (ib., p.52)

Here we follow the definition of power given by Lasswell and Kaplan (1950, p.75). "Power is participation in the making of decisions: $\mathrm{G}$ has power over $\mathrm{H}$ with respect to the values $\mathrm{K}$ if $\mathrm{G}$ participates in the making of decisions affecting the K-policies of $\mathrm{H}$ ", together with the necessity of threats and use of sanctions "to sustain a policy against opposition" (ib., p.76). We assert that, whereas the agents in group G typically refer to the owners and suppliers of capital inputs (and $\mathrm{H}$ to the labourers), Warrant Economics has distorted this pure capitalist cause. The Call-Put policies (analysed below) have been redefining the composition of the $\mathrm{G}$ and $\mathrm{H}$ groups and have further skewed both the allocation of control of the production process and the distribution of claimancy rights on the economic surplus. We argue that the majority of the productive and organic tissue of the society is relegated to a passive, exploited, and deprived participant in the bespoke power game of the aristocracy of Warrant Economics. In the light of the growing public disquiet about the functioning of the market system, our work could serve as a blueprint for explaining the seeds of the Great Recession and as such allow the $99 \%$ movement to possess an intellectual compass.

\subsection{The Systemic Creation and Preservation of Inequality}

In its first phase, Warrant Economics unfolds by the creation of Call and Put policy options, implicitly written by the neoliberal state and its symbiotic economic institutions, which, in turn, are distributed for free to the noble family of the modern market kingdom:

\footnotetext{
${ }^{5}$ Dubbed as the Crown Prince of the Chicago School by Stigler (1974).
} 
financial institutions and big multinationals. ${ }^{6}$ Warrant Economics is the profound example of the recently much maligned 'Originate and Distribute' model of financial engineering; through its practice, the neoliberal consensus ensures that the wealthy top 1 percent (or even less) has an institutional right to milk the sacred cow of global growth in a privileged way. We view the adverse concentration effects in market competition and distribution effects for incomes as the two sides of the Warrant Economics coin.

\subsubsection{The Institutional Power of the Call}

The Call option offers unlimited upside wealth potential over and above a rolling strike price (in financial engineering terms, a cliquet or ratchet contingent claim that resets the strike of the derivative structure to the last fixing of the underlying asset) determined by the nominal income of those at the bottom 99 per cent of the distribution. This exercise price may be adjusted (highly contentious in the present age of austerity) by expected inflation and a positive (albeit small) growth rate; the latter ensures economic stability according to theorists - in our opinion, it merely preserves the Warrants status quo.

We outline forthwith key policies that shape the architecture of the global market landscape and engineer the perpetual in-the-moneyness of the call options for the golden few.

1. Favourable regulatory/tax policies, exploitation of regulatory/tax arbitrage, and the existence of tax havens (most of them operating under the British Crown's jurisdiction).

2. Freeing of capital movements, deregulation of global capital markets, and openness of the financial sectors of emerging and developing economies.

3. Privatisation of natural resources irrespective of the ensuing costs of environmental damage and natural resource depletion.

4. Flexible labour markets that lead to outsourcing and herald the dominance of the "worst employer" in the most profitable "social haven". This has been reinforced by the collapse of the Soviet Union releasing hundreds of millions of new workers in the world economy, thus creating a global reserve army of labour. The end result is imported (in developed economies) downward pressure on the combined wage, direct and indirect (the latter, in the form of depleted employment rights, social benefits and related state provisions).

\footnotetext{
${ }^{6}$ Neoliberal, in the sense that the embracing of a market economy has effectively become synonymous to serving the interests of big business. We should also point out that, in the context of Warrant Economics, Call-Put policies feed 'financialisation', a term referring to the engagement of non financial businesses in financial markets (Stockhammer, 2004).
} 
5. 'One model fits all' economic policy prescriptions - i.e. slashing of public spending, open and flexible markets - that the IMF's dogmatic thinktank systematically imposes on countries with borrowing needs. The two other bodies with global reach, namely the WTO and the World Bank, act as complementary custodians of the Call Option's privileges.

In short, in the name of globalisation, liberisation of capital markets, structural reform and flexibility in the labour markets, Call policies have triggered a competitive arms race on a global scale to maximise tax, social, and ecological dumping with exponential returns to their holders.

Statistics speak volumes. "Between 2000 and 2006 the US economy expanded by 18 per cent, whereas real income for the median working class dropped by 1.1 per cent ... Meanwhile, the top tenth saw an improvement of 32 per cent in their incomes, the top 1 per cent a rise of 203 per cent the top 0.1 per cent a staggering gain of 425 per cent" (Financial Times, 2008, October 29). Economists of the Washington consensus have labelled such a wealth redistribution 'median wage stagnation' and are stunned about the complexity of the problem and its causes. Others dub it the 'silent recession'. While the real income for the poorest $20 \%$ of the US population was decreasing by an annual rate of $0.7 \%$ over the 2000-2007 period (US Congress, Joint Economic Committee, 2008, June 26), George W. Bush joked "This is an impressive crowd. The haves and the have-mores. Some people call you the elite. I call you my base" during the 2000 Alfred E. Smith Memorial Foundation Dinner (this is an annual charity fundraiser for Catholic Charities).

Piketty and Saez (2006) examine the evolution of incomes in the US from 1917 to 2002, and find that the overall pattern of top income shares over the century is U-shaped. In particular, the top percentile fluctuated "from about $18 \%$ before WWI, to only about $8 \%$ in the 1960 s and 1970 s, and back to almost $17 \%$ by 2000 " (ib., p.201), reaching $18.3 \%$ in 2007 (Alvaredo et al., 2011). The rise in income inequality is further documented by Wolff and Zacharias (2006) who show that, over the 1982-2000 period, the share of the top percentile increased from $9.9 \%$ to a staggering $17.4 \%$, using the standard measure of money income, or from $14.1 \%$ to $20.1 \%$ when the authors use their measure of wealth adjusted income.

The Financial Times (2010, July 30) point out that "the annual incomes of the bottom 90 per cent of US families have been essentially flat since 1973 - having risen by only 10 per cent in real terms over the past 37 years. ... Over the same period the incomes of the top 1 per cent have tripled." We should note that, although the increase in the share of the top percentile has been accompanied by the exceptional growth in top executives' pay relative to the salaries of employees, the issue of whether the so called 'working rich' have replaced top capital owners (the 'rentiers') at the top of the economic ladder is beyond 
the scope of this essay. ${ }^{7}$

Nevertheless, the report in the Financial Times (2010, February 3) is quite informative: "A packed session at the World Economic Forum in Davos last week addressed the issue of executive compensation and the huge rise in the pay gap between chief executives and ordinary workers in their organisations. ... The best-paid person in a US company was paid about 40 times that of the worst-paid person a generation ago. Now the multiple is about 300. ...Asked whether the reason was that management had improved hugely; executives were underpaid in the past; their jobs were more onerous today, or whether executives had collectively exploited market power to raise their salaries, all of the members of the panel agreed that the last possibility was closest to the truth."

Interestingly, the current situation parallels the 'gilded age' of the 1920s that gave rise to unprecedented Great Gatsby-style incomes at the top and was brought to an end by the 1929 stock market crash and the ensuing Great Depression. Saez (2010) shows that for the US, the distribution of income today almost matches that of 1928 on the eve of the Wall Street crash. In 1928, the top 1 percent of Americans took in 24 per cent of national income compared with 23.5 per cent in 2007 and 20.9 percent in 2008 (ib., Figure 2). More disturbing is the observation that the income share of the top $0.01 \%$ in 2008 was 5 percent, a level only achieved in 1928. Notably, since then, this share had been trending downwards until 1978 when it had reached 1 percent (ib., Figure 3).

In the era of globalisation, it is of no surprise that the inequality developments in the US are mirrored in the rest of the world. Edward (2006) uses density and growth curves to offer a holistic analysis of global poverty, growth, and inequality. His results show that the bottom $50 \%$ of the world's population received less than $10 \%$ of the global growth in the 1990s. ${ }^{8}$ According to Llense (2010, p.1) "the sharp increase in globalization and the last privatization wave have promoted the shaping of a market for executives in France." In Japan, traditionally considered as an egalitarian society, inequality has been rising since the eighties. Moriguchi (2010, p.7) links this increase "with a faster growth of wage income at the high end of the distribution" but notes (p.23) that the recent increases in the top $1 \%$ wage group are modest when compared to those in the US. Gustafsson and Jansson (2008) show that the top of the income distribution in Sweden has developed more favourably than for other groups since the eighties, with the highest centile experiencing the most rapid increase. In Germany, Biewen and Juhasz (2010) argue that from 2000 to 2006 there was an unprecedented rise in net equivalised income inequality and poverty.

\footnotetext{
${ }^{7}$ For example, Wolff and Zacharias (2006) do not support this issue, whereas Piketty and Saez (2006) argue in its favour. Although "Forbes popularised the term 'working rich', the magazine used it in the sense that the wealthiest Americans hold jobs rather than in the sense that the wealthiest depend mainly on labour income as their chief source of income" (Wolff and Zacharias, 2006, p.12).

${ }^{8}$ It should also be noted that "Middle-income earners (outside China) had the lowest relative consumption growth. For the roughly one billion people between the 50th and 70th percentiles, consumption hardly changed from 1993 to 2001" (ib., p.1682).
} 
Regarding the rich-poor divide in the UK, it is wider now than 40 years ago according to the report of the National Equality Panel: An Anatomy of Economic Inequality in the UK, January 2010. ${ }^{9}$ Strikingly, the share of the top $1 \%$ of the income distribution decreased from around $17 \%$ before WWII to around $6 \%$ in the second half of the $1970 \mathrm{~s}$, and regressed to $14.6 \%$ by 2007 (Alvaredo et al., 2011). We further read in the Financial Times (2011, May 13): "In 1979 a person in the top 1 per cent of earners would have had income three times that of the median person. The income multiple had risen to 4.4 times by 1996-97 and then to 5.6 times by 2009-10." The high pay commission, set up in November 2010 to scrutinise the rising pay of those at the top of the public and private sectors reported that, while over the 1949-1979 period the share of income going to the top of the distribution had been dropping, today the top $0.1 \%$ of earners take home as big a percentage of the national income as they did in the 1940s. The High Pay Commission (2011, p.6) further claims that "If current trends continue... we will have gone back to levels of inequality not seen since Victorian England."

In this light, we cannot agree more with the point made by Bowles and Gintis (2000, p.1434) "in the opening pages of his Principles, Marshall defined one of the chief tasks of our discipline this way: Now at last we are setting ourselves seriously to inquire whether it is necessary that there should be any so called 'lower classes' at all ... the answer depends in a great measure upon facts and inferences, which are within the province of economics; and it is this which gives to economic studies their chief and their highest interest. We suspect he would be disappointed in what economics has accomplished toward this end over the intervening century, ... throughout the world."

- In our view, the escalating income inequality is a symptom of Call policies. It is very well known in finance that the beneficiaries (top 1 per cent of income earners and, even more emphatically the top 0.1 percentile) of in-the-money warrants dilute the claim of incumbent shareholders (bottom 99 per cent of income earners) of the company (national wealth).

Another major destabilising consequence of Call policies is the reduction of the share of wages and salaries of a country's GNP (or GDP), and the accompanying increase in profits. For the US alone, the share of wages and salaries in the annual GNP went down from 54.9\% in 2000 to its lowest level since 1929, 51.6\% in 2006 (Aron-Dine and Shapiro, 2007). Notably, during the 2001-06 expansion, while wages and salaries grew at a 1.9 percent average annual rate (after adjusting for inflation), corporate profits increased by 12.8\% (ib., p.1). According to The Economist (2006, June 17th), since 2000 "The fruits of productivity gains have been skewed towards the highest earners, and towards companies,

\footnotetext{
${ }^{9}$ See also the Joseph Rowntree Foundation "New poverty and wealth maps of Britain reveal inequality to be at 40-year high", 17 July 2007, www.jrf.org.uk
} 
whose profits have reached record levels as a share of GDP." Up to the unveiling of the crisis in 2007, such developments have typically led to either overinvestment by businesses or a shortfall in aggregate demand. When wages trail productivity ${ }^{10}$ spending can keep up with output only by the expansion of consumer debt. In the US, the ratio of household debt to GDP jumped from $75 \%$ in 2000 to $104 \%$ in 2007 (BIS, 2009), providing golden opportunities for the exploitation of inequality by reputed holders of Warrants, as we shall unwind in the second facet of Warrant Economics in the following section. For example, "The Fortune 500 largest U.S. companies slashed a record 821,000 jobs last year, even as their collective profit soared more than three-fold to $\$ 391$ billion, according to the business magazine" (Reuters, April 15 2010, 'Fortune 500 shed record 821,000 jobs in 2009' by Phil Wahba).

- With the uncovering of the function of Call policies, the adage 'we spend more than we produce', used by goverments to justify the recent austerity debacle, represents the insult after the injury to the bottom 99 percent of the public.

\subsubsection{The Institutional Power of the Put}

The Put option provides limited downside loss for large and systemically important firms (predominantly, systemically important financial institutions (SIFIs). ${ }^{11}$ In its primary form, it is struck at the worth of the distressed/insolvent or substantially undercapitalised institution and, typically, protects the rights of creditors. The payoff to the holders of the Put is the cost to the general public of the state funded rescue or bailout plan(s). ${ }^{12}$

For the financial system in particular, secondary Put benefits include (i) deposit guarantees which, for financial conglomerates, fund the overleverage of their investing arms, and (ii) periodic capital injections, or even the purchase of 'bad assets' by the state at strike prices well above market values. Thus, the provision of the Put effectively proclaims: no matter at what cost, funded by the taxpayer, you are too big to fail, even if

\footnotetext{
${ }^{10} \mathrm{It}$ is important to say that the labour income share, seen in the light of the wage-productivity relationship, is intricately associated with the so-called wage gap:

$$
\frac{\text { wages }}{\mathrm{GDP}}=\frac{\text { wages } / \text { employees }}{\mathrm{GDP} / \text { employees }}=\frac{\text { wage }}{\text { productivity }},
$$

i.e. the labour share can be expressed as the ratio of average real wage and productivity. If, say, a $10 \%$ productivity gain is accompanied by a $10 \%$ growth in the average real wage, then the wage gap is zero. On the other hand, the lower the wage growth, the more wages trail productivity gains and thus the higher is the wage gap.

${ }^{11}$ We do not claim originality of the term. 'Greenspan's Put' refers to the salvation plans of the Fed's Chairman after the collapse of the giant hedge fund Long Term Capital Management in 1998, and the cushioning of bankers from the fatal excesses of their practices ever since.

${ }^{12}$ There is an important difference between financial bailouts and sovereign "bailouts". "These official 'bailout packages' consist of interest bearing loans which in effect replace maturing private debt; if grants were given instead, this would be an entirely different story as it would lower government indebtedness and hence risk" (Chamley and Pinto, 2011, p.1).
} 
you are a zombie bank. Besides the obvious creation of moral hazard, another immediate and severely destabilising effect of the Put option is the dominance of the highest risk taker, safeguarded by 'heads-I-win, tails-you-loose' type of Put Warrants. As a consequence, risk management is degraded to a mere cost function, serving as a compulsory (albeit detached) monitoring unit which can only restrain profitable business.

The unprecedented socialisation of a firm's own internal systemic risks via (partial or full) nationalisation of financial institutions such as AIG, Citigroup, Fannie Mae, Fredie Mac, Fortis, Lloyds, Northern Rock, Royal Bank of Scotland (the list is far from exhaustive) has evidenced another dire aspect of the 'reward for failure' that the Put underwrites. As we read in the Financial Times (2009, March 3), "Vikram Pandit, Citigroup's chief executive, poses the issue in stark terms. When the U.S. government announced further support, he was reported as telling analysts: We completely remain in day-to-day charge of the company. We are going to run Citi for shareholders." At that time the US taxpayer had already injected to Citi's coffers $\$ 45$ billion with the value of external equity merely $10 \%$ of the state's funding. Despite partial ownership and the supply of a plethora of implicit Put-type insurance policies mentioned earlier on, the taxpayer has been void of any authority in shaping strategy, direction and restructuring of the failed behemoth.

Bailing out banks/financial institutions is carried out under the presumption that they will increase lending. However, the monetary policy response to stimulate growth by the US Federal Reserve (and other central banks like the Bank of England) in the form of quantitative easing has not been channeled into facilitating business activity, as banks have been hoarding money to pump-up their balance sheets. Excess reserves have risen dramatically: from 1.9 bil $\$$ in August 2008 to 796.8 bil $\$$ in January 2009, to 1583.5 bil $\$$ in August 2011. ${ }^{13}$ According to Edlin and Jaffee (2009, p.2) one of the reasons that banks decide to leave all this money parked at the Fed is that "ironically, the Federal Reserve has started to pay interest on excess reserves, a change that increases bank incentive to hold, rather than to lend, these reserves." An aversion to piling up more illiquid risk and the lack of trust between bankers due to the frailty, complexity and opacity of their balance sheets' exposure, makes them content with the 25 basis points that the Federal Reserve banks are offering instead for seeking higher returns through lending.

The toxic culture though of the world's super-sized finance reigns supreme in the midst of the economic crisis. The social costs for servicing the soaring levels of massive recovery plans that are channeled for their rescue (totalling several trillion worldwide), and the adverse knock-on effects on health, education, eradication of poverty, and social welfare expenses are dismissively regarded as mere collateral damage by the powerful corporate networks, necessary for their longevity and prosperity. No matter how huge the social cost of their predicaments is, granted by an abundance of Warrants, corporate elites will never

\footnotetext{
${ }^{13}$ http://www.federalreserve.gov/releases/h3/hist/h3hist1.txt
} 
be disabused of their unquestioning belief in grandeur. This attitude is hardly surprising given that the provision and distribution of Warrants is influenced by (i) senior bankers who, since the late 1990s, have gradually infiltrated the commanding heights of public life in the US by taking office (e.g. Jon Corzine, Hank Paulson, Robert Rubin), and (ii) corporate lobbyists who try to shape the political agenda via generous donations and fundraising activities for the benefit of the main political parties/authorities.

An example of the latter is the Business Roundtable, BRT (www.businessroundtable.org), founded in 1972 and consisting of the chief executives of most of the largest US-based corporations and banks. "The BRT is particularly influential over US international trade policies. In the early 1990s a Roundtable front group USA*NAFTA spent $\$ 10$ million to help secure the controversial North American Free Trade Agreement. In 2000 the Roundtable successfully campaigned for unconditional access to US markets for goods US corporations produce in China under commercially ideal, but often socially and environmentally deplorable, conditions. They spent over $\$ 30$ million on lobbyists to help Congress members make up their mind". ${ }^{14}$

The BRT's successes in shaping political decision making inspired corporate leaders in Europe and elsewhere to create similar lobby groups (e.g. the European Roundtable of industrialists launched in 1983, www.ert.be). Brussels, the centre of the European Union with over 12,000 corporate lobbyists, rivals Washington as the world's corporate lobbying capital. Notably, "The City of London has its Brussels lobbying headquarters opposite the European Commission head office. ... Yet the City of London is absent from the Commission's lobby transparency register" (WDM, 2010, p.28). The EU also follows the US in terms of its high official/banker 'revolving doors': "Three former Commissioners have taken up positions with Goldman Sachs at the end of their term; Peter Sutherland, Karel van Miert and Mario Monti" (ib.). Interestingly, as sovereign debt crisis in the Eurozone is turning to a watershed for reshaping economic policy to smite the welfare system (see Section 5), Mario Monti became in November 2011 the (unelected) prime minister of Italy to offer his technocratic wisdom in credibly steering the country into fiscal austerity and averting a market shutdown for the funding of national debt.

Stiglitz (2009) neatly outlines the institutional power of the put by pointing to "another problem with America's too-big-to-fail, too-big-to-be-restructured banks: they are too politically powerful. Their lobbying efforts worked well, first to deregulate, and then to have taxpayers pay for the cleanup."

The multifarious array of benefits for the banking industry of the Warrant Economics Put and the secure power that it grants to its holders to continue their pernicious practices, were glaringly evident during 2009/10 when the premature presumption was that the global economy has seen off the worst of the crisis. Following the pumping by the US

\footnotetext{
${ }^{14}$ New Internationalist 347, July 2002, p.15.
} 
government in October 2008 of the first portion of the $\$ 700$ billion Troubled Asset Relief Programme (TARP), nine large banks in the US got $\$ 125$ billion (in 2009, Bank of America got $\$ 20$ billion more) in bailout funds. Subsequently, in early 2009, banks were subject to stress tests, in fact not so stressful for many, ${ }^{15}$ and having met the requirements for reserves/capital adequacy, more than half of the largest banks were declared as solvent, having enough capital to survive a worst case scenario (see Time Magazine, September 26, 2011, p.38). Within a couple of months, the banks involved did start paying back the emergency TARP funds, allowing them to resume their customary operations.

At first glance, it seems that banks have repaid their life support, the Put's premium, that kept them afloat at the peak of the crisis. This is entirely illusory and unashamedly immoral. The refund by banks to the public purse, at very convenient credit terms, was for the amount of a "loan", the state-funded capital injections to their balance sheets, which represents a miniscule fraction of the true Warrant Economics Put's payoff that they silently appropriate. Have banks paid back the cost of the state purchases of their "bad" assets at above market prices? Have banks paid back their profits for having the worthless Credit Default Swaps issued by the collapsed Lehman Brothers settled at par by the then Treasurer, Hank Paulson? Have investment banks like Goldman Sachs paid for the privileged status of a 'holding company' that were granted in the aftermath of 2008 ? Have banks paid back any of the estimated $\$ 10$ trillion cost to the taxpayer of the various implicit or explicit guarantees? Not really, we suspect.

Instead, as the Barclays' bank chief executive Bod Diamond (facing the Treasury Select Committee on 11/1/11) infamously declared, "There was a period of remorse and apology for banks. I think that period needs to be over." The total employee compensation subsidised by the publicly funded Put for the five US large banks - Citigroup, Bank of America, Goldman Sachs, JPMorgan Chase and Morgan Stanley - was $\$ 130$ billion in 2010, up from $\$ 96$ billion in 2008 (ib.); in the same vein, profits were subsidised. The article 'Goldman Sachs: Don't Blame Us' in the BusinessWeek, April 1 2010, by Roben Farzad is illuminating: "Eighteen months removed from the depths of the financial crisis, Goldman posted a $\$ 13.4$ billion profit in 2009, a Wall Street record. ... After Blankfein sat for an interview with the London Times in November 2009, he famously quipped, when he thought he was off the record, that he was just a banker "doing God's work"." For the divine holders of Calls and Puts, hubris will never lead to their nemesis.

\footnotetext{
${ }^{15}$ The main purpose of the stress tests was to assure the markets that banks hold enough reserves for residential mortgages. Many experts though opined that reserves for commercial real estate were too small and there were no reserves for impairment of sovereign debt. Worse, regulators never tested the capacity of banks to fund themselves adequately if implicit or explicit state guarantees of their non-deposit liabilities were withdrawn.
} 


\subsection{Exploitation of Inequality via Securitisation}

Reading the first chapter of Warrant Economics presented above, one begins to assimilate the haute-cuture tailoring of the true neoliberal straightjacket. Despite the veil of illusion, created by the mantra of the ruling academic and political orthodoxies, of the benefits-for-all that "laissez-faire market competition" brings on a global scale, Warrant Economics unveils the real rules of market fundamentalism (or, else, the distorted market competition). In this respect, it is worth quoting the classical liberal of the 1930s Chicago school, Simons ([1934]1948, p.42): "The representation of laissez faire as a merely donothing policy is unfortunate and misleading. It is an obvious responsibility of the state under this policy to maintain the kind of legal and institutional framework within which competition can function effectively as an agency of control."

Warrant Economics though offers a contrasting narrative. Create and sustain inequality via the Call-Put synergies, thus ultimately building the secluded kingdom of 'Wealthistan' in which only the plutocrats are granted residence and are meticulously safeguarded (Put policy options) - the fatal consequences of their actions only affect the peasantry of the global economic landscape.

The second facet of Warrant Economics, and the precursor of the current global economic crisis, is the phenomenal proliferation of innovative forms for the exploitation of inequality by its main stakeholders. A once in a lifetime unregulated securitisation of the public's needs for various forms of material welfare, which cannot be satisfied through squeezed real incomes, took place after the burst of the new economy bubble in 2000 . In the new millennium, the means of inequality exploitation have traversed beyond the familiar avenues of the wage-productivity gap and the existence of a global reserve army of labour (notably, even such traditional exploitation routes have been off the mainstream literature map). The dreams of the modern peasantry for affordable housing are highjacked by the salesmanship, short termism, and irresponsible fees culture of high finance that rendered the real and durable asset of house ownership to a speculative and worthless piece of paper.

The finance and banking industries, having the lion's share of Warrants, fully exploited the state's donation during the credit expansion in the first part of the noughties. They were equipped with an as good as cash structural collateral (Calls-Puts) and operated in a period of a historically low cost of immediacy/liquidity (created by the Fed's interest rate policies and mimicked by central bankers elsewhere to curtail the adversity of the dotcom shock). As a result, they levered up their stake in the society by securitising illiquid assets (subprime mortgages, distressed loans, etc.) via innovative, yet opaque forms of over-thecounter credit derivatives (collaterilised debt/loan obligations and derivatives written on them). In the context of an unregulated environment, they created extremely profitable (mainly, fees-driven) business for themselves. 
For the US alone, Martin Wolf in the Financial Times (2008, February 5) notes: "the profits of financial companies jumped from below 5 per cent of total corporate profits, after tax, in 1982 to 41 per cent in 2007, even though their share of corporate value added only rose from 8 per cent to 16 per cent." And in a later article, Financial Times (2010, April 21), he observes that "The UK case is dramatic, with banking assets jumping from 50 per cent of GDP to more than 550 per cent over the past four decades... The combination of state insurance (which protects creditors) with limited liability (which protects shareholders) creates a financial doomsday machine." A snapshot is also worth noting: "In 2007 big financial corporations posted record profits - more than $\$ 70$ billion in Britain alone - along with record complaints about bad service." (New Internationalist, April 2009, 'The Banks Bankrupting the World.')

The institutional change that facilitated the extreme proliferation of off-balance sheet contingent claims and the explosion of the shadow banking system, with the devastating effects that we are currently experiencing, was the successive relaxation and final repeal of the Glass-Steagall Act in the US that took place in 1999 under the auspices of the Financial Modernization Act. Senators' Glass and Steagall Act of 1933 put forward the separation of commercial and investment banking for financial conglomerates. History repeats itself; the excesses of the finance industry in the pre Glass-Steagall Act era, which led to the Great Crash and the depression of the 1930s, have been rejuvenated by the 1999 "diversification" of financial conglomerates into commercial and investment activities. ${ }^{16}$ In effect, they have been free to use retail deposits, which are explicitly guaranteed by the government, as collateral for speculative trading and toxic financial engineering to create internal hedge funds with stratospheric leverage relative to their capital basenumber. As Kregel (2010) argues, the deregulation associated with the erosion of the (Glass-Steagall) section 20 restrictions on bank activities led to a situation where both the asset and liabilities sides of financial institutions were leveraged.

Four years into the crisis and the day of reckoning for the banks' reckless pursuit of bumper profits (concurrent with insane personal bonuses) is still way out of sight. Multiple regulatory reforms to tame their activities (Basel III requirements at a global level; Capital Requirements Directive IV in Europe; Dodd-Frank act in the US; Vickers Commission report in the UK; Solvency II rules for the European Insurance Industry) are still uncoordinated, thus open to regulatory arbitrage when implemented. Structural reform of the universal banking model to ringfence (a feeble compromise on the necessity for a complete break-up) the retail and commercial services from the systemically risky investment banking arm, together with enhanced capital and liquidity requirements are

\footnotetext{
${ }^{16}$ In Britain, restrictions on the activities of financial institutions were substantially weakened as a result of market liberalisation and the regulatory 'Big Bang' of 1986. Although in other European Union countries universal banks were present well before, they became aggressive in wholesale markets and securities trading only recently in imitation of the Anglo-American model.
} 
being cynically contested by a throng of coordinated lobbyists.

This self-interested group, seizing on the stagnant economic environment, delivers bloodcurdling warnings about the consequences of a restructuring. First, we are told that lending to businesses for productive investment and lending to consumers will be choked-off; in reality, this is a small component of their balance sheet compared with the huge portion directed to the interbank market. Second, the regulatory reforms will increase the cost of capital to investment banking, and reduce leverage and profits - in our opinion, a positive outcome that will halt excessive risk taking, curb short-term rewards and redistribute funds to SMEs that create jobs for the wider economy and contribute to socially beneficial growth. Third, the new environment will potentially shift the risk of lending from banks to unregulated shadow banking institutions, such as hedge funds, private equity and industrial firms' finance branches. Without understating the need to place "shadow" entities under close supervision and strict capital rules, it defies logic to claim that the risks of internal shadow banking operations of universal banks were adequately assessed and managed by their risk management systems up to the onslaught of the crisis. All in all banks want the put and the high return on equity...

Despite the ethereal illusion of containment of the virulent practices of financial institutions, the trinity of their operations - securitisation, engineering and speculation - still reigns supreme and takes full advantage of deregulation to ratchet up their profitability in commodities trading. Rising commodity prices, soaring food prices in particular, compress the purchasing power of wages/salaries in developed nations and mean hunger for the citizens in the least developed world.

It is true that China's growth, and of other emerging economies, together with biofuel production have led to the commodity price bubble. At the same time, it is becoming an unassailable belief that the morphing of exchange traded commodities into a class of asset-backed securities has intensified price fluctuations due to financialisation rather than market fundamentals.

Traditionally, commodity futures exchanges have offered a transparent, safe and regulated market environment for hedging and speculation. The bankruptcy of MF Global on October 31 2011, one of the world's largest futures brokers has resulted in $\$ 600 \mathrm{~m}$ losses for its customers, embarrassing regulators and reviving calls for tougher rules. ${ }^{17}$

\footnotetext{
${ }^{17}$ As recent as June 2011, the president of the Futures Industry Association, the brokers' lobbyist in the Washington administration, John Damgard "proudly testified to the US congress that no futures broker failed during the crisis and no customers lost money because of regulatory failures" (Financial Times, 2011, November 11). Under the command of Wall street insider, Jon Corzine, MF Global "failed to uphold what its own sales brochure called a "cardinal safequard" of futures trading: keeping customer and house funds separate" (ib.). Account segregation is a "sacrosanct" according to "Daniel Roth, the president of the National Futures Association, an industry-funded self-regulatory body for US futures markets" (ib.). As a blunt testament for the revolving doors of power, MF Global won in February 2010 fast track approval by William Dudley, the New York Fed President and a former colleague of Jon Corzine at Goldman Sachs, to join the Wall Street elite of about 20 primary brokers to carry out monetary policy,
} 
It is worth reminding that, after the Wall Street crash in the US, the Roosevelt government recognised that speculative futures contracts were causing actual commodity prices to be highly volatile and introduced the Commodity Exchange Act of 1936. Regulations such as 'position limits' prevented excessive speculation by limiting the amount of derivatives traded in a particular market (thus, averting 'banking on hunger'), while still enabling farmers to use derivatives to hedge their risk. In 1991 Goldman Sachs created a commodity index fund which, after severe lobbying by the financial industry, was exempted from position limits. On the basis of an equally weighted index of commodity futures, the findings of Gorton and Rouwenhorst (2006) that such commodity futures have (i) a risk premium about equal the equity premium and higher than the bond premium, and (ii) less downside risk relative to equity returns, were quite influential. Commodity index funds became a widely used speculative vehicle in food commodity markets, inflating both the level and volatility of prices: "As early as April 2006, Merrill Lynch estimated that speculation was causing commodity prices to trade at 50 per cent higher than if they were based on fundamental supply and demand alone" (WDM, 2010, p.9).

The Guardian (2011, 29 June) correctly points out that the historically low interest rates, sustained by the injection of trillions of dollars of quantitative easing (QE) cash into the banking system, turned away investors from low-yielding government bonds and savings accounts, thus fueling the speculative demand for commodities. It is estimated that the amount invested in commodity index funds increased from \$46bn in 2005 to $\$ 250$ bn in March 2008 and hit a record $\$ 451$ bn in April 2011, more than 40 times higher than a decade ago (ib.; and WDM, 2010, p.10).

The rapid proliferation of exchange-traded funds (ETFs) among big institutions and private investors and the huge expansion of their product suite are raising fresh sobering destabilizing threats for an already frail global economy. It is estimated that the industry has expanded by $40 \%$ a year for the past decade and as of April 2011, has nearly $\$ 1,500$ bn assets under management among an estimated 2,670 ETFs in existence (Financial Times, 2011, June 5). To their defenders, ETFs offer a cheap, transparent (since listed on exchanges), and sensible financial innovation which enables both institutional and, more crucially, individual investors to gain access to a host of different investment classes. "With ETFs, every retail investor with an internet connection can make their own attempt at being a global macro hedge fund manager" potentially engaging in split-second

distributing US debt as part of the Federal open market operations (Financial Times, 2011, November 6). All this, with a mere $\$ 1$ bn in capital, a position 30 times weaker than that of most primary dealers like Goldman Sachs, Deutsche Bank, Barclays Capital etc. The MF Global debacle came when Jon Corzine, having leapt the company's leverage ratio to 40 to 1 , placed a $\$ 6.3 \mathrm{bn}$ bet - six times its capital - on risky European government debt which turned sour (ib.). When asked why MF Global was granted the status of a primary dealer, "the US Federal Reserve Chairman Ben Bernanke defensively responded that the central bank was not the firm's regulator" (ib.). Does the whole episode and the failure of a self-regulating market give another uneasy sense of deja-vu? 
trading and moving between asset classes several times in the same day (Financial Times, 2011, May 27). Sceptics point out that ETFs enable and encourage herding, speed up markets, ${ }^{18}$ and encourage short termism (ib.). It can thus be argued that ETFs represent a further cause for price turbulence in food commodity markets that leads to an escalating impoverishment in the developing world.

Recently though, the alarming range of complex and opaque synthetic ETFs ${ }^{19}$ offered by banks to (i) generate higher returns, (ii) get around the proprietary trading ban (introduced in 2010 for investment banking), and (iii) raise funding against illiquid portfolios that cannot be normally financed in the repo market, is turning reminiscent to the toxic product suite of exotic credit derivatives. In case of poor performance, such derivatives may lead to yet another economic disaster due to their highly contagious and deleterious effects.

Analysing the degenerating state of economic affairs in its two facets of creating/sustaining and exploiting inequality, a question is desperate for an answer. How did market fundamentalism come to dominate the economics profession and why were the Call-Put policies of the twisted market competition allowed to roar undisturbed? In the next section we argue that the economic paradigm associated with the Warrant Economics state of capitalism received the eulogy of professionals under the fallacious view that economics stands for the "physics of society".

\section{Marketing Economics as "Physics of Society"}

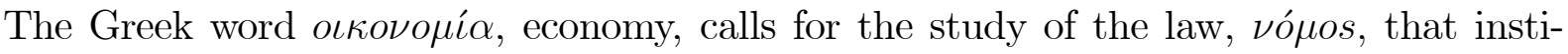
tutions inflict upon the social functioning of the citizens of the house, oíkos, the latter typically in a loose sense depicting either a social micro-unit or a macro one (city, or $\pi o ́ \lambda \iota s$, in the ancient Greek city-state political structure). Since the publication of The Wealth of Nations in 1776, widely acknowledged as the birth of political economy, economic discourse has traversed avenues that their diversity is more striking that their similarity. The starting perception of classical economists (Smith, Mill, Marx) that political economy is an all-embracing social science was first challenged in the writings of Ricardo in which the historical, the institutional, and the factual faded into the background. This mindset

\footnotetext{
${ }^{18}$ As, for example, during the "...Wall Street's equity "flash crash" of May 2010, when share prices of many companies plummeted in a matter of minutes for little obvious reason. ETFs accounted for $70 \%$ of cancelled trades that ensued - despite representing only $11 \%$ of securities in the US." (Financial Times, 2011, June 5).

${ }^{19}$ Unlike physically replicated ETFs where the funds own at least some of the assets, synthetic ETFs, representing nearly half of the market in Europe and becoming dominant in Asia as well, earn their return through a derivative, typically a swap from the parent bank. The boutique of ETF structures has expanded to "short" ETFs which offer a positive return if the assets involved fall in value, "leveraged" ETFs which promise an above normal return and "actively managed" ETFs which may provide a choice over the underlying assets. (Financial Times, 2011, June 5.)
} 
evolved to the marginalists (Jevons, Walras) and, subsequently, to the dominance of the neoclassical orthodoxy's view in Mises and Hayek's reorientation of the Austrian school - over alternative multi-disciplinary approaches offered by the German historical school (Roscher, Schmoller) and the British historical school (Leslie, Cunningham, Asley), or American institutionalism (i.e. Veblen, Commons, Mitchell) - that economics as a scientific discipline should be separate and alien to the other social sciences. ${ }^{20}$

A nearly 200 years old rich scientific tradition, replete with famous and typically interminable intellectual battles, with diverse methodological forms of enquiry, full of enduring controversies about what economists could and/or should explain came to a halt by the univocal adoption by the orthodoxy of the axiomatic, ultra-deductivism of the 1950s general equilibrium "theory". Reinforced by a totalitarian reliance on abstract micro foundations, solely driven by strong priors on the form and purpose of our social science and the mathematical necessity that a pure closed logical system entails, the dominant paradigm offered a pseudo-positivist demarcation criterion about what is acceptable as scientific economic theory and what is not: a priori micro foundations equals "theory"; all competing accounts of institutional, social, and historical aspects in economics are synonymous to story telling. The central aim of the established priesthood was to retreat economics to a phlogiston state that makes it part of natural rather than social sciences, elevating economics to (seemingly) value-free "physics of the society". Solow (1986, p.2526) put the point in remarkable clarity: "My impression is that the best and brightest of the profession proceed as if economics is the physics of society. There is a single universally valid model of the world. It only needs to be applied. You could drop a modern economist from a time machine - a helicopter maybe, like the one that drops the money - at any time, in any place, along with his or her personal computer; he or she could set up in business without even bothering to ask what time and which place."

Here is the fallacy of the view of economics as the physics of society. As the physicists Steinhardt and Turok (2007, p.234) point out "The theory may turn out to be mathematically beautiful and philosophically appealing. And then ... the theorists may wake up one morning, connect to the Internet, and learn about a new observation that completely kills the idea." Like many scientists, the authors "feel it is important to insist that science should remain based on the principle that statements have meaning only if they can be verified or refuted. Ideas whose assumptions can never be tested lie outside the realm of science" (ib., 234). Any principle that relies "on untestable assumptions, is never at risk of being proved wrong. On this uneven playing field, few will feel encouraged to seek scientifically refutable alternatives." (ib., p.235)

Notably, when physicists confronted the natural microcosm they embraced what have

\footnotetext{
${ }^{20}$ See Milonakis and Fine (2009) for an excellent exposition of the method, the social and the historical foundations in the evolution of economic theory.
} 
become the fundamental tenets of quantum theory: (i) Heisenberg's uncertainty (or indeterminacy) principle, i.e. "it is impossible to know an object's precise position and its velocity at the same time"; (ii) the wave-particle duality, i.e. "all matter particles and force fields come in discrete, indivisible energy packets that can exhibit both particlelike and wave-like characteristics, depending on the circumstances", ${ }^{21}$ and (iii) Bohr's argument on the complementarity between the particle- and wave-like representations.

"Einstein had devoted his life to probing into that objective world of physical processes which runs its course in space and time, independent of us, according to firm laws. ... Later in his life, also, when quantum theory had long become an integral part of modern physics, Einstein was unable to change his attitude - at best, he was prepared to accept the existence of quantum theory as a temporary expedient. "God does not throw dice" was his unshakable principle, one that he would not allow anybody to challenge. To which Bohr could only counter, "Nor is our business to prescribe to God how he should run the world."” (Heisenberg, [1971]1985, p.171)

One could compare and contrast the quantum theorists' insights for the microcosm and their relation to the macrocosm that physicists ponder (incidentally using extremely sophisticated and rigorous technical apparatuses) to the mechanistic wisdom of the a priori, axiomatic camp of economists, or more accurately, "social" mathematicians. ${ }^{22}$ Their vision is tangential to the Alchian thesis: the view that competition represents a Darwinian selection mechanism that produces exactly the same outcome that would ensue from a world in which consumers maximised utility and businessmen maximised profits (Blaug, 1992, p.249). Their main syllogism is that the ever utility maximising agents will (via the invisible hand) produce aggregate outcomes, i.e. the micro sanctuary of the representative agent will evolve to a sustainable and realistic (!) macro equilibrium.

It is worth noting that the concept of the representative agent is strikingly at odds with the Darwinian perspective: "Darwin made a radical break with the typological tradition of essentialism by initiating an entirely new way of thinking. What we find among living organisms, he said, are not constant classes (types), but variable populations. ...Within a population, in contrast to a class, every individual is uniquely different from every other individual. ...Darwin's new way of thinking, being based on the study of populations, is now referred to as population thinking. ... [This] is the foundation of modern evolutionary theory and one of the basic constituents of the philosophy of biology." (Mayr, 2001, p.75)

Regarding our understanding of the universe, Einstein developed his own model of the cosmos on the basis of his seminal theory of gravity (general relativity) and argued that

\footnotetext{
${ }^{21}$ Steinhardt and Turok (2007, p.74-75).

${ }^{22}$ A remark made by Robert Lucas to Patinkin (cited in Backhouse, 2002, p.189) is telling: "your use of the term 'mechanical' as a pejorative applied to theories, and our discussion of this in class. This helped push me to the extreme view ... that well-formulated theories are machines, and therefore necessarily mechanical."
} 
it is static. Hubble proved empirically in 1929 that the universe is not static; although the idea of an unchanging universe was revived in the 1950s, the discovery of the cosmic background radiation by Bell Laboratory astronomers in 1963 gave the final blow to the steady-state model. In the early 1990s, the discovery of the existence of dark energy made it clear that the axiom 'gravity always attracts' applies only to some forms of energy, like ordinary (visible) matter and dark matter. Other forms of energy, like dark energy, can gravitationally repel. Steinhardt and Turok (2007) take us beyond the Big Bang into the Endless Universe with their authoritative exposition of cosmological theories and the emergence of an alternative model that challenges the accepted view for the universe.

In their exploration, cosmologists define space as flat if two parallel laser beams, sent off in any direction in three-dimensional space, never cross or diverge; if the two initially parallel light beams intersect, space has a positive curvature and the universe is closed; on the other hand, an open universe has a negative curvature and the two parallel light beams diverge. Since scientists cannot travel back in time and thus cannot perform direct experiments on the universe, they gather indirect information about its history by launching satellite missions. An example is the WMAP (Wilkinson Microwave Anisotropy Probe) equipped with highly sensitive detectors to gather some of the ancient light emitted from the dark layer about 14 billion years ago. The WMAP measurements, announced by NASA (National Aeronautics and Space Administration) in February 2003, showed conclusively that the curvature is negligible and space is nearly flat - research in physics seeks to explain this fundamental feature of the universe. Furthermore, the WMAP 7-year results released on 26 January 2010 demonstrated that dark energy makes up 73\%, dark matter $23 \%$, and ordinary matter is only about $4 \%$ of our universe.

If it is difficult for physicists to find simple, all-encompassing explanations for the fundamental mechanisms underlying nature (such as Newton's laws of motion), how can economic "theorists" be trusted when they claim to have developed a universal model for human economic activity?

Nevertheless, we should point out that the impressive discoveries of Galileo (1564-1642) led scientists across the disciplinary spectrum to believe that all nature functioned as a large cosmic clock, subject to the laws of physics. Following the seminal demonstration by William Harvey (1578-1657) that our heart functions like a pump, the French philosopher René Descartes (1596-1650) argued that the material brain was a complex machine obeying the laws of physics, entirely distinct from the immaterial mind. The machinelike cosmos replaced the ancient Greek viewpoint that nature as a whole is a living organism, and the brain/mind dichotomy dominated science for about four hundred years. However, recent developments in neuroscience argue in favour of the plasticity of the brain versus a hardwired system, as state-of-the-art laboratory analysis demonstrates that brain maps are neither immutable within a singe brain nor universal. This fundamental brain prop- 
erty of 'neuroplasticity' is in stark contrast with the old wisdom of 'localisation', i.e. a mechanistic brain with specialised parts (for a fascinating journey through the frontiers of brain science see Doidge, 2007). ${ }^{23}$ A neuroplastically informed view of human activity implies a bidirectional feedback between brain and culture - brain and genetics give rise to culture, while culture shapes the brain.

The Great Recession vindicates the degenerating status of the research programme of the economic orthodoxy prevailing since the 1980s. ${ }^{24}$ This comes as no surprise given (i) the fallacious view of economics as the physics of society, and (ii) the implication of modern evolutionary theory and modern neuroscience that the concept of the representative agent is defunct. In what follows, we will demonstrate that the Great Recession cannot be seen as an unpredictable tsunami-like event but, instead, it is a symptom of the regressive neoliberal policies that, over the years, put Warrant Economics on solid ground.

\section{Warrant Economics: Too Big, Too Concealed, Too Rewarding (for the few) to Fail}

\subsection{The Background}

The historical footprint of Warrant Economics is marked by Lionel Robbins ([1932]2007, p.15) definition: "Economics is a science which studies human behaviour as a relationship between ends and scarce means which have alternative uses." The marginalist traditions are thus rounded off and, by singling out the rational choice under constraints, economics is deprived from its main enterprise to study the formation of the 'Wealth of Nations' and its distribution. It subsequently opened up the (in)famous gates of the positive, (arguably) value-free, (seemingly) neutral with respect to the objectives of economic policy, microfounded form of enquiry, and elevated such a methodological monism as the sole scientific modus faciendi of economics.

As a result, the revival of interest in the Walrasian general equilibrium system (relegated to a mere appendix in Marshall's Principles as Blaug (1992, p.168) argues) attains its apotheosis with the ultra-deductive work pioneered by Arrow and Debreu (1954), among others. The study of the causes and conditions of material welfare is dictated by the positivist Paretian efficiency criterion, i.e. the preclusion of outcomes in which mutual gains remain unexploited. This is formally expressed in the two Fundamental Theorems

\footnotetext{
${ }^{23}$ Doidge (2007, p.212-213) explains Descartes' motivation for the brain/mind dichotomy and comments on its effect: "His noble attempt to rescue the brain from the mysticism that surrounded it in his time, by making it mechanical, failed. Instead the brain came to be seen as an inert, inanimate machine that could be moved to action only by the immaterial, ghostlike soul Descartes placed within it, which came to be called 'the ghost in the machine'. By depicting a mechanistic brain, Descartes drained the life out of it and slowed the acceptance of brain plasticity more than any other thinker."

${ }^{24}$ The term 'research programme' is borrowed from Imre Lakatos ([1978]1999).
} 
of Welfare Economics which, in a nutshell, "prove" that unfettered market competition and exchange produce Pareto optimal equilibrium allocations. Whereas the First Theorem shies away from matters of distribution, it is left to the Second Theorem to assert that wealth redistribution cum Walrasian exchange represents a mechanism capable of achieving any feasible Pareto optimum. In that vein, general equilibrium theory becomes the 'be all' and 'end all' ad gloriam apparatus. ${ }^{25}$

Social efficiency, which raises penetrating questions of equity/distributive justice and ethical concerns about the operation of a competitive market system, is in effect ostracised from the playground of positive economics. To his credit, Arrow (1970, p.4) was blatantly clear about the welfare theorems' schema: "Any complaints about [the competitive price system's] operation can be reduced to complaints about the distribution of income, which should then be rectified by lump-sum transfers. Of course, as Pareto already emphasized, the proposition provides no basis for accepting the results of the market in the absence of accepted levels of income equality. ...The price system itself determines the income distribution only in the sense of preserving the status quo. Even if costless lump-sum transfers are possible, there is needed a collective mechanism reallocating income if the status quo is not regarded as satisfactory." Despite Arrow's clarifications for the limitation of the price system to produce equitable results without the aid of a collective agency (e.g. government), GE paved the way for the concomitant developments made by, mainly, the Friedman inspired Chicago assembly line of rational expectations, natural rate of unemployment, efficient (financial) markets hypothesis and real business cycle models.

This modernist fairy tale has the following narrative. First, the economy is a selfcontained and self-regulated entity, housing exogenous institutions, inhabited by a rational, self-regarding, fully informed and forward-looking representative agent with exogenous preferences. Second, the technology utilised is superficially modelled by an aggregate production function exhibiting non increasing returns to scale. ${ }^{26}$ Third, complete and enforceable contracts (or, in Coase's tradition, no impediments to efficient and costless bargaining) are exchanged in competitive markets. All in all, the neoclassical research programme spells an equilibrium associated with an allocative distribution that is Pareto optimal.

A flavour of 'Keynesian economics' - sharply distinguished from the 'economics of Keynes' by Leijonhufvud (1968) - was absorbed into the neoclassical mainstream in the

\footnotetext{
${ }^{25}$ It is worth quoting Hutchison (2000, p.315): "For what GE analysis has done to Smith's conjecture is to eviscerate it of real-world content, and transform it into a piece of "rigorous", empirically vacuous, hyper-abstract analysis, based on a range of fantastic, science-fictional assumptions."

${ }^{26}$ It has been known for a considerable time that it is not possible to derive an aggregate production function from individual production functions, even as an approximation (Fisher, 1969). Joan Robinson's view $(1978$, p.76) is particularly caustic: "... the production function has been a powerful instrument of miseducation." The convenient argument that the aggregate production function often gives satisfactory statistical fits does not rescue its adoption (Felipe and McCombie, 2005).
} 
form of the neoclassical synthesis and, more recently, into what Goodfriend and King (1997) have coined as the new neoclassical synthesis. The latter assimilates the benchmark rational expectations/real business cycle model with new Keynesian elements of imperfect competition, sticky prices and market frictions. The ensuing dynamic stochastic general equilibrium (DSGE) setting, a "honorific label" as argued by Solow (2008), offered the rationale for the macroeconomic policy of inflation targeting, aka the new consensus in macroeconomics, which was adopted universally by central bankers and policy makers in the pre-2008 era as the undisputed, rollercoster macroeconomic dictum.

DSGE models - both the purist neoclassical and new Keynesian versions - were poised to offer a logically closed, theoretically coherent framework (for the self-referential criteria of their advocates in the academic macroeconomics orthodoxy) which would adequately identify structural "shocks" within its own narrowly defined sphere of interactions. All this, despite the tensions between the two camps (see, for example, Chari et al., 2009), in our opinion, cursory for their suspicious policy relevance. Their stock of the make-believe knowledgeable technical superiority assumes that the passage of time, and the concomitant systemic uncertainty that it entails, is simply depicted as a calculable risk represented by a discount/risk aversion rate; institutions do not evolve, aggregate relationships are of the same form as those obtained by the optimising decision rules of the homogeneous rational individual. Global and housing market variables that proved central to the transmission of the financial crisis are largely in absentia, the existence of systemic bubbles is a priori dismissed, the role of government and fiscal policy is given limited license.

Understandably, Solow (2008, p.245) is "left with a puzzle, or even a challenge. What accounts for the ability of "modern macro" to win hearts and minds among bright and enterprising academic economists?" For Chari and Kehoe (2008, p.249) "the answer is simple: the attractions of modern macroeconomics are similar to the attractions that led Robert Solow to develop the growth model and James Tobin to develop portfolio theory and Paul Samuelson to develop the overlapping generations model. These economists, like others before and since, were attracted to using what was then the frontier of economic theory in an attempt to shed light on the day's challenging macroeconomic questions."

However, we should point out that for a battery of models that are christened as relevant for policy decision making by central bankers and treasurers alike, one would normally expect, at the very minimum, that plausible interactions between macroeconomic and financial variables would be a central theme in such settings; in reality though, even financial variables do not feature in the implementation of macro DSGE models. In his thorough survey of some of the recent macro-finance literature and the associated models used by central banks, Smith (2009, p.10) argues that "The reason that only real variables are used to evaluate DSGE macro models is that for many financial variables, the standard theory does not work, or only works with such long and variable lags as to be irrelevant 
to the policy issues. The fact that the theory does not work is reflected in the prevalence of 'puzzles' of which there are many."

Nevertheless, the "central problem of depression-prevention has been solved for all practical purposes" declared Lucas (quoted in Krugman, 2008, p.9) in his 2003 presidential address to the American Economic Association. Woodford (2009) argued that there has been convergence of views, a pervasive fallacy in our opinion, in fundamental macroeconomic issues: (i) models with coherent intertemporal general-equilibrium foundations should be used, (ii) quantitative policy analysis should be based on econometrically validated structural models, (iii) model expectations as endogenous, (iv) real disturbances are an important factor of economic fluctuations, and (v) monetary policy is effective, especially in terms of controlling inflation. In the light of such wide agreement, he concludes that "... prospects are unusually bright for progress with lasting consequences, due to the increased possibility of productive dialogue between theory and empirical work on the one hand, and between theory and practice on the other." (ib., p.277)

The Great Recession is challenging the 'received view' in macroeconomics and makes people to realise that this glittering scientific scalpel is, in one operation after another, killing many a patient. ${ }^{27}$

\subsection{Reality Verdict}

The looming question that has to be addressed is how laissez faire economics, the supremacy of which was presumed by the neolibertarian philosophy to be hardwired in the mindset of economists, has been transformed to a state of Warrant Economics. The Call-Put policies of the latter suffocate competition for SMEs, concentrate control rights, operate under oligopolistic forms of production (thus enjoying non competitive, mind-boggling profits), and distort the distribution of the surplus of the world's economy produce. In other words, how ever is it possible that instead of being competitive 'price takers', the 'price makers' of today's oligopolistic behemoths of Warrant Economics prevail.

The answer to this striking conundrum is twofold. First, the segregated discourse between the mere rhetoric of the fundamental welfare theorems and the subtle possibilities of the general theory of the second best introduced by Lipsey and Lancaster (1956-57). "The general theorem of the second best states that if one of the Paretian optimum conditions cannot be fulfilled a second best optimum situation is achieved only by departing from all other optimum conditions. ... The theory of the Paretian optimum is concerned with the conditions that must be fulfilled in order to maximize some function subject to a set of constraints which are generally considered to be 'in the nature of things'." (ib., p.12) A plausible corollary is that a production unit which generates more than a Pareto-optimal

\footnotetext{
${ }^{27}$ The term received view is borrowed from McCloskey (1983, p.481-517).
} 
level of output can be contained if it becomes a monopoly, thereby restricting output. Otherwise, the competitive output level set at a price that equals marginal cost could, in this case, reduce rather than enhance (Paretian) welfare. In a general equilibrium setting, monopolies are not only possible but "are proved" even optimal! Alas, "theory", shielded by stratagems, ${ }^{28}$ endorses too profitable and too big to fail monopolistic entities.

Second, through the devious dialectic in the neoliberal strand of economics between a conspicuous apathy towards the real state of capitalism and the ferocious attempts to legitimize the existence and practice of global monopolies. ${ }^{29}$ Galbraith's (2004, p.24) passage is castigating: “The phrase 'monopoly capitalism,' once in common use, has been dropped from the academic and political lexicon."

Although the intellectual contortions necessary to compass such a faculty of thought beggar belief, a few remarks stand out. However one twists its auxiliary assumptions, the neoclassical theory of the firm, is inapplicable to situations of oligopoly (cf. Blaug, 1992, p.157-160). In addition, "There is no oligopoly theory. There are bits and pieces of models: some reasonably well analyzed, some scarcely investigated. Our so-called theories are based upon a mixture of common sense, uncommon sense, a few observations, a great amount of casual empiricism, and a certain amount of mathematics and logic" (Blaug, 1992, p.157, quoting Shubik, 1970, p.415).

It is particularly pertinent to our thesis on Warrant Economics the switch from the ideals of liberalism to neoliberalism made by the Chicago school and its followers in the early 1950s and the 'shifting attitude toward concentrations of business power' (Van Horn, 2011). Simons ([1934] 1948, p.43) noted: "Thus, the great enemy of democracy is monopoly...", and argued for the "Elimination of private monopoly in all its forms... 1. Through drastic measures for establishing and maintaining effectively competitive conditions in all industries where competition can function as a regulative agency..., and 2. Through gradual transition to direct government ownership and operation in the case of all industries where competition cannot be made to function effectively as an agency of control" (ib., p.57).

One may compare and contrast the libertarian philosophy of Simons to the post-1950 Chigago-school research agenda that the distortive effects in the production and welfare process of monopolies/oligopolies are rather benign and that the dynamic process of rivalry between giant corporations will produce results that approximate the outcome of a perfectly competitive process. It is beyond the scope of our present work to review such a voluminous endeavour of artificially camouflaging the role and impact of monopolies

\footnotetext{
${ }^{28}$ As Popper calls the ad hoc hypotheses or mere linguistic devices, i.e. the auxiliary hypotheses which save a theory but do not satisfy certain well-defined conditions (see Lakatos, 1978, p.33).

${ }^{29}$ We use the term monopoly in a loose sense, referring to productive units enjoying market power to affect prices, output, and investment in an industry, and being able to impose barriers to entry. Throughout our thesis, monopoly and oligopoly are interchanged.
} 
- for that matter see Foster et al. (2011, p.15-16) who highlight the works of, among others, Coase on the 'Nature of the Firm' that introduced transactions costs to rationalise corporate vertical integration, Williamson on the efficiency arguments of markets and hierarchies, and Bork on the 'Antitrust Paradox'.

In the meantime, reality bites: a tangible proxy of the competitive first best is asphyxiated, the second best flirts with an oligopolistic settlement, and the sacrosanct competitive market is transformed into a playground of concentrated power through the Call-Put services of Warrant Economics. In fact, for the US, the evidence provided by Foster et al. (2011, p.5) "suggests that economic concentration is greater today than it has ever been, and it has increased sharply over the past two decades."

Warrant economics unravels the real life conditions that form a conglomerate. Not through exogenous violations of the fictitious assumptions of the first best paradigm. Neither through the elegy of a distorted competitor, who inexplicably departs from a Paretian competitive quota, and is castigated by the second best. Nor through the Chicago-school inspired dictum that market-generated monopolies are efficient allocators of resources and price utility. But instead, via an institutionally facilitated mechanism that erects productive entities that dominate any feasible competitive alternative through Call-Put patronised economies of scale.

Our analysis contains echoes of the works of (i) Baran and Sweezy (1966) who substituted the law of falling profit in competitive capitalism with the law of rising surplus in monopoly capitalism, ${ }^{30}$ (ii) Steindl ([1952]1976) who explained the Great Depression of the 1930s as a logical outcome of the monopolistic functioning of the capitalist system, and, to a larger extent (iii) Kalecki ([1952]2009) who conclusively argued that "The degree of monopoly has a general tendency to increase in the long run and thus to depress the relative share of wages in income..." (ib., p.30), and "Moreover, if the effect of the increase in the degree of monopoly upon the distribution of national income is not counteracted by other factors [e.g. intensity of innovations] there will be a relative shift from wages to profit, and this will constitute another reason for the slowing down in the long-run rise in output" (ib., p.161). Furthermore, our thesis is tangential to the work of Braudel (1979) - see Wallerstein (1991) for an exposition of Braudel's view of capitalism. Braudel saw capitalism not as the establishment of a free, competitive market but, instead, as the system of the antimarket, i.e. the zone of concentration and a relatively high degree of monopolisation. He further perused the entwined functions of the state as (i) a regulator that contains the forces of the antimarket, and thus promotes competition and freedom, and (ii) a guarantor of monopoly.

\footnotetext{
${ }^{30}$ The authors state that this substitution does not reject the time-honoured classical-Marxian theorem of the tendency of the rate of profit to fall, as "we are simply taking account of the undoubted fact that the structure of the capitalist economy has undergone a fundamental change since that theorem was formulated." (ib., p.72)
} 
Finally, in the first rounds of the Great Recession, there has been a rediscovery of Keynes (1936) 'General Theory' and the need for expansionary fiscal policy to counter the slump. It is worth noting that the assumption of a perfectly competitive environment, the rare, if at all, mentioning of the impact of monopolies, and the absence of any distributional issues are all conspicuous in the work of Keynes. Thus, it is hardly surprising that despite the fiscal stimuli, Warrant Economics has become stronger in terms of concentration of power and surplus, monopolistic profits, reserves and cash hoarding by banks and big corporations, lack of productive investments, high levels of unemployment and growing inequality.

\section{In the Slipstream of Warrant Economics: The Sov- ereign Debt Crisis}

The latest piece in the canvas of the Great Recession, and the even Greater Confusion that impedes the enunciation of the underlying causes of our woes, unfolds in 2011 by the escalating eurozone sovereign debt crisis and the first time ever downgrade of the US to AA+ by Standard \& Poor's, one of the rating agencies. Alarming statistics for the poor state of the real and banking sectors, high and persistent unemployment rates, together with a pessimistic outlook for growth in the US, Japan and the European Union, all contribute to a new wave of turmoil in global capital markets and bring closer to sight the trauma of a second great meltdown.

Despite the renewed tremors though, the cauldron of Warrant Economics capitalism remains firmly based on its ideological grounds and is meticulously stirred by its bastions. In the midst of economic stagnation and rising unemployment, it unleashes a ferocious attack on the last remnants of the european welfare state, the indirect wage that has shielded the middle class from the wilder ravages of top-down capitalism and has averted social carnage in previous recessions, and on Medicare and Social Security programmes in the US. Such a fresh assault is grounded on the fetishism of short-term fiscal consolidation and AAA sovereign rating.

A forceful private-public-academic (PPA) partnership is formed to ringfence the preservation of Warrant Economics through a new wave of neoliberal economic policies with a twofold effect: (i) the strangle of the SMEs engendered by both a prolonged credit draught instigated by bailed-out banks in need of recapitalisation (while big multinationals are able to fund themselves directly from capital markets at historically low interest rate levels) and an escalating shortage of effective demand (as the flow of spending in the real economy is curtailed by the draconian fiscal austerity measures undertaken in most industrial countries - bar US for the moment), and (ii) the further squeeze of the bottom $99 \%$ of the 
income distribution. In effect, monopolistic entities and the slice of the pie accruing to the top $1 \%$ of the income distribution are being progressively firewalled from an open-ended rivalry for power and distribution of the global economic surplus.

The stakes are high for the custodians of Warrant Economics - politicians, finance ministers, central bankers, and austerian academics. ${ }^{31}$ On one hand, to discredit the model which provides economic welfare through progressive taxation (a Pigou-Marshall type of tax and subsidies structure) and sits alongside a private enterprise economy. A social democratic model ${ }^{32}$ that formed the basis of the post-WWII successful settlement in Western Europe and, despite the political innuendos, is taking a viable hold on the current administration in the US. On the other, to reinstate the badly bruised, by the economic crisis, ideology of the followers of Friedrich Hayek's and Milton Friedman's neoliberalism preaching that, within a basic framework of law and morality, any attempts by governments to influence the Alchian process of the market would be counterproductive and doomed to fail.

In doing so, there is laborious work to be carried out by the PPA partnership: the private sector failure that led to the Great Recession must be reprofiled as a public sector crisis; the narrative is that "excessive" state spending in many western democracies has led to "unsustainable" debt and deficit levels that will inhibit future growth and pause a major threat to welfare. At the same time, the battered status of the supremacy of the (oligopolistic) market has to be rekindled in the minds of the public as the most efficient allocator and utiliser of scarce resources. Ultimately, the practice of socialising the costs of reckless private risk taking and lending, while at the same time securing wild profits in the private coffers, needs to be reengineered.

Lifelines and market leverage for the PPA project are given in abundance by the practice of rampant private sector species: bond vigilantes (mainly, institutional bond holders), and the unregulated market of over-the-counter Credit Default Swaps (CDS) - especially of the naked variety - populated by traders and investors with a voracious appetite for speculative short-term profits that can only materialise in the shadows of a collapsing sovereign. Ironically, throughout the Great Recession, creditors have been the main beneficiaries of the Warrant Economics Put and just as culpable for their conspicuous non vigilant lending in the pre-2008 era as the currently stigmatised sovereign debtors. All these, under the aegis of the unrated cartel of the rating agencies whose procyclical actions further destabilised the economic system without being curtailed by regulators.

It makes a mockery though of the technocratic wisdom of the rating agencies, and

\footnotetext{
${ }^{31}$ In a similar spirit, Krugman (2010) notes that "the policy elite - central bankers, finance ministers, politicians, who pose as defenders of fiscal virtue, are acting like the priests of an ancient cult, demanding that we engage in human sacrifices to appease the anger of invisible gods."

${ }^{32}$ Initiated by the policy proposals of the German revisionist Eduard Bernstein and the founder of the British welfare state William H. Beveridge.
} 
defies their underwritten clarion call for fiscal tightening, the fact that US 10-year bond yields (post downgrade to $\mathrm{AA}+$ ) are hovering in the record low vicinity of $2 \%$; Japan, the world's second largest government bond market at $\$ 7,900 \mathrm{bn}$ (Y 875,000 bn, US being the first at $\$ 9,500 \mathrm{bn}$ at the end of 2010) has lost its stamp of AAA rating since 2002, and in 2011 has been downgraded by S\&P to AA-. The "catastrophic" consequence: Japan's 10-year bond yields are millennia low at around 1\% despite debt to GDP ratio well above $200 \%$ and eye-catching primary deficits. In a nutshell, even if one subscribes to the "flight to safety" tentative argument, markets are short of supply of Japanese and US bonds, despite the much heralded fiscal frailties of these economies. This is a clear aberration from the poster case made by the economic and policy elites that fiscal austerity is a virtue in its own right to avert an alleged future economic perdition.

Despite the habitual and opportunistic tensions in the PPA group to convince the leading economies (that issue their own currency) of the rightfulness of fiscal consolidation, there is a uniform urge for prolonged austerity measures in Eurozone members caught in the spotlight of the sovereign mayhem and trapped in an asymmetric monetary system. Notwithstanding the political capital invested to corroborate the contrary, the latter is turning out to be a flawed economic experiment; a precarious illusion lecturing that, as long as fiscal deficits are tamed, the prowess of the policies of the ECB will eventually enable the transition to a prosperous Euroland where performance and competitiveness will be converging. Within a decade of its creation, Eurozone is gradually morphed to an economic settlement uncommunicative to (i) the perils of the diverse balance of payments of its participants, a diversity which was thought to vanish by default in the adopted theoretical models of small open economies interacting under a common currency, and (ii) the traumas of structural current account deficits that lead to escalating net external liabilities - lubricated by the unscrupulous (albeit profitable) lending practices of banks.

Besides an alarming (or not) percentage of GDP, we view the origins, dynamics, and disparate benefits behind the accumulation of sovereign debt in the Eurozone South (and elsewhere) as a complex socioeconomic phenomenon which grants the myriad of creditors with unassailable and opaque powers to undermine national independence. In a colonialtype fashion, technocratic inspectorates are dispatched to swarm over the ministries of debt-ridden countries, highjack fiscal policy and impose shock therapy "rescue" plans, push through state selloffs at collapsing market prices and enfeeble democracy, the most sacred founding principle of the states of the European Union. ${ }^{33}$ All this, despite the

\footnotetext{
${ }^{33}$ In the context of Warrant Economics, we reserve for future work to examine the multitude of causes for the emergence of government budget deficits and to take stock of the main beneficiaries of the accumulation of national debt. It is worth pointing out that the startling clarity of the balance sheet of a country's gross domestic (national) product, GDP, offers an invaluable apparatus for such a task. Kalecki (1952, p.45-52) offers an authoritative and illuminating exposition. In short, drawing from the fundamental identity of national accounts, i.e. the income and expenditures sides of GDP are equal, we obtain:
} 
growing conviction that the economic benefits of piling on debt are predominantly accruing to the "structural mercantilists of the core"34. For example, Brecht et al. (2010) argue that "Germany's growth strategy continues to rely heavily on sustained deficits (public or private) in other European countries." The ruling mantra is that high government indebtness is a deadly virus to be contained, and expansionary fiscal policies should be heading to oblivion.

The intellectual input to the PPA affiliation by austerian academics is mainly grounded on the highly debated Ricardian equivalence proposition that public debt issuance is equivalent to taxation. This view was cautiously speculated (for practical policy prescriptions such as the funding of military conflict by 'war bonds') by Ricardo ([1846]2009) and reexamined and affirmed by Barro (1974). The conventional view in public finance theory had been that "...the issuance of government debt stimulates aggregate demand and economic growth in the short run but crowds out capital and reduces national income in the long run" (Elmendorf and Mankiw, 1998, p.1-2). However, the view of government debt that has been immensely influential within the academic circle since the mid 1970s, and eventually took hold, is the Ricardian equivalence. In Barro's neoclassical ivory tower of rational expectations, perfect and efficient capital markets with no liquidity constraints, with the future path of government spending fixed and known to the economic agents who adhere to a permanent income hypothesis and to a life-cycle model of savings, any attempts by the state to stimulate aggregate demand by increasing debt-financed government spending will have no net effect. ${ }^{35}$ In his review of the literature, Seater (1993,

$$
\begin{aligned}
\text { profits }+(\text { wages, salaries })+\text { taxes } & =C+I+G+(X-M) \Rightarrow \\
\text { profits }+(\text { wages, salaries })-C & =I+G-\operatorname{taxes}+(X-M), \text { or } \\
S & =I+G-\operatorname{taxes}+(X-M),
\end{aligned}
$$

where $C$ is consumption, $S$ denotes savings, $I$ is private investment, $G$ is government spending, $X$ is exports and $M$ denotes imports. The core of the balance sheet debate (private versus public stimuli for growth) can be captured neatly after a final rearrangement of the above identity:

$$
\begin{aligned}
S-I & =(G-T)+(X-M) \text {, i.e. } \\
\text { net savings } & =\text { budget deficit }+ \text { export surplus }
\end{aligned}
$$

Note that in a monetary union, where a member state cannot devalue to boost its exports and put a brake on its imports, a current account deficit can be compensated by private sector investment or government budget deficits. That is, when $(X-M<0)$, the private sector has to invest more than it saves $(S-I<0)$ or the public sector has to increase its spending $(G-T>0)$ to balance the country's national accounts. In case of a balanced current account, budget deficits reflect private sector surpluses.

${ }^{34}$ To use the term of Martin Wolf in the Financial Times, October 19, 2011, 'There is no sunlit future for the euro'.

${ }^{35}$ In particular, Barro (1974, p.1116) argued that "there is no persuasive theoretical case for treating government debt, at the margin, as a net component of perceived household wealth. ... in the case where the marginal net-wealth effect of government bonds is close to zero ... fiscal effects involving changes in the relative amounts of tax and debt finance for a given amount of public expenditure would have no effect on aggregate demand, interest rates, and capital formation." As Feldstein (1976, p.332) points out "A 
p.143) found that two conclusions were clear: "The first appears uncontroversial: it seems almost impossible that Ricardian equivalence holds exactly. ...The second conclusion is far more controversial: despite its nearly certain invalidity as a literal description of the role of public debt in the economy, Ricardian equivalence holds as a close approximation."

In the context of Warrant Economics though and in the midst of the worst crisis of post-WWII capitalism, we ponder: Is a redistribution of income through intergenerational transfers that aim to smooth future tax hikes, that will be necessary to pay off the current debt bonanza (the thrust of Barro's syllogism), a viable possibility or a pervasive fallacy? We find ourselves asking the ominous question:

- A squeezed bottom $90 \%$ of the income distribution - undergoing a long real wage stagnation, staring at weak labour and housing markets (the US is experiencing a record rate of mortgage delinquencies, foreclosures), living under a credit crunch, and loaded with record levels of debt bequeathed by the unprecedented securitization of inequality (see Section 2) - can it ever realistically produce the level of net savings required to neutralise the wealth effect of short-term sovereign debt expansion?

The top decile may afford to practice their duty for intergenerational altruism that the Ricardian equivalence theory prescribes, surely not the bottom $90 \%$ peasantry. Once more, the voodoo abstractions of the neoclassical drivel abstain from income distribution issues and silence the life-cycle impoverishment of the middle class. Once again, the rational forward-looking actions of the omnipotent and omnipresent representative agent, feeded (we speculate) by what else could it be but 'helicopter money', will validate the irrefutable "theory" that nullifies futile government debt and spending on social security: "...my conclusion is that government debt (and social security) will not add to net wealth in a model with operative intergenerational transfers (either from old to young or from young to old)" (Barro, 1976, p.343). In that vein, Lucas dismissed the recent $\$ 800$ billion worth fiscal stimuli plan in the US as 'schlock economics' and his Chicago colleague John Cochrane argued that its rationale is based on discredited "fairy tales". (See Krugman, 2009.)

Scholars though may reflect on our economic heritage; in his autobiography, Robbins (1971) regards his dispute with Keynes on the fiscal expansion issue during the Great Depression "as the greatest mistake of my professional career" (ib., p.154). Thinking back on his anti-expansionary perspective he confesses: "How had I got myself into this state of

novel feature of Barro's model is that each individual's utility depends not only on his own consumption but also on the utility of his immediate heir. The utility of the current generation therefore depends indirectly on the utility of all future generations. The introduction of government debt creates wealth for the current generation but a liability for a future generation or generations. The current generation will resist this redistribution from their heirs to themselves by increasing their bequests by just enough so that their heirs are no worse off. The extra saving for this additional bequest just offsets the reduced savings that would otherwise be associated with the government debt." 
mind? ...the trouble was intellectual. I had become the slave of theoretical constructions which, if not intrinsically invalid as regards logical consistency, were inappropriate to the total situation which had then developed and which therefore misled my judgement" (ib., p.153).

Such introspection and mea culpa though are grotesquely absent from the mindset of the PPA partnership in addressing the deeper causes of the ongoing Great Recession. Friedman's (in)famous dictum that the Great Depression was a mere monetary phenomenon, and his disquisition that the onus is on the US Federal Reserve to have prevented it by boosting the supply of base money, are still shaping the magna carta of core macroeconomic policy making. In dealing with our economic doldrums, expansionary fiscal policy is, on the top of the contested Ricardian equivalence, decried as a liability in crowding out the potency of the private sector. A delusive marketopian spell that feeds the neoliberal envision that public cutbacks and fiscal shutdown will automatically spur private investment.

In turn, we are told to believe in optical illusions: the recapitalised banks - at whatever bill the wider society is having to foot for their solvency - will eventually, through the mechanism of fractional reserve banking and the money multiplier, boost (via lending) economic growth, employment, and prosperity. Instead, and contrary to the patronising of policy makers' theorising, the Put's benefits from the plethora of state-funded capital injections in the forms of troubled asset relief program (TARP), quantitative easing, implicit or explicit guarantees of their toxic assets (mortgages in the US, sovereign assets in the Eurozone) are being amassed in the coffers of the banking industry. Its gumption is the continuing pursuit of bumper profits that could mimick the "party" era of the fifty times (50x) multiple by which a bank's equity was typically leveraged in 2007 - at the heights of the virulent shadow banking and the apogee of the silent securitisation of inequality (see Section 2) - generating Returns on Equity (ROE) ${ }^{36}$ of up to $25 \%-30 \%$ (five times the norm for many blue-chip industrial companies), and artificially boosting executive pay.

Nowadays, leverage ratios are down to around 20x, the shabby building blocks of their profitability are exposed, manipulable risk-weighting internal systems that allow the buildup of systemic risks are questioned, and more equity is demanded by regulators to fund bank assets (nothing close to the order of $40 \%$ equity required to fund the asset base during the 19th century). The assemblage of bank responses to the request of taking some responsibility for their own follies during the bygone heydays, and, more importantly, the lack of trust between them (one has only to look at recent LIBOR rates that are heading towards the 2008 levels) materialises in the threat of accelerating hoarding and internal

\footnotetext{
${ }^{36}$ The banks' own preferred measure which has historically flattered performance by relating returns only to thin equity cushions, rather than Returns on Assets (ROA) which takes into account the toxicity of their complex loan portfolio and the consequences of unscrupulous lending.
} 
recapitalisation through a loan shutdown; temporarily suspending dividends and slashing bonuses are alien to their lexicon.

So we are left to ponder once more: are we witnessing another fallacy of composition? Banks are deleveraging to salvage their existence and avert nationalisations, the public sector through self-inflicted, ideologically grounded austerity agendas is deleveraging, the bottom $99 \%$ of households are confronting a real purchasing power regression. However camouflaged the lack of aggregate demand is, the burning question is still looming large: where will sustainable and equitable growth (not a repeat of the debt-fueled kind of pre-2007) will originate from? For the western countries that issue their own currency, devaluations could in principle restore competitiveness; however, this is a zero sum game if each country follows such recourse at the same time. Shouts to surplus countries, e.g. the BRICs and their Eurozone equivalent (e.g. Germany), to boost their own domestic demand to facilitate net exports of troubleshoot economies are in vein.

For the Eurozone periphery, stalemated in a sovereign debt peril, loaded with structural external deficits, internal price devaluation is the only option; but in the light of the extinction of competition by SMEs, that could lower prices, and the dominance of monopolistic/monopsonistic price setters, internal deflation becomes synonymous to punitive wage deflation and impoverishment of the vast majorities. Explicit fiscal transfers from surplus nations, stimulatory policies in the core, ECB acting as the unlimited lender of last resort for sovereigns whose access to febrile bond markets is banned, and aggressive monetary easing (not fueling further rounds of destabilising financial speculation) are an anathema to the European elites. What else stands out to kick start "recovery"? Large corporations siting on a pile of idle cash, amashed by the concentration of economic surplus facilitated by the Warrant Economics synergies, waiting to pump it into new investment. Will it be socially beneficial on a wide scale, or a further step towards their dominance and unfettered profiteering? Our solicitous view is that an economy cannot be saved by the incubators of its malaises. 


\section{Conclusions}

Our thesis on Warrant Economics unravels a power mode of insiders' capitalism of the last thirty years that through the costless appropriation of an intricate cobweb of institutional Call-Put policy options has had a twofold influence. First, it has distorted competition in the market system and accelerated economic concentration, thus commissioning rivalry predominantly among big corporations with a global reach. Second, it has entitled the free-market aristocracy of the top $1 \%$ of the income distribution to sail safely in the storming waters of the Great Recession, preserving their soaring remuneration. We argue that adverse concentration and income effects constitute the two sides of the Warrant Economics coin.

Central in the many-layered tapestry of Warrant Economics are its two symbiotic elements: (i) the systemic creation and preservation of inequality via Call-Put endowments, and (ii) the systemic exploitation of inequality via novel and toxic forms of securitisation. We further attest to the major destabilising consequence of (Call) policies manifested by the falling share of wages and salaries in a country's GDP and the accompanying increase in profits, a phenomenon that fueled the epidemic of mounting consumer debt.

We identify a puissant private-public-academic partnership prescribing the neoliberal dogmas of small-state government, low-tax economy (embedding huge tax cuts for the wealthy), and minimum regulation for big businesses. A PPA project fervourously preaching that outcomes generated by "free" markets are optimal and efficient, the rational results of "natural" economic forces that self-regulate and equilibrate themselves. Portraying economics as the analogue of the "physics of society", a fallacious and degenerating research programme in our opinion, serenaded an aura of infallibility for their wisdom.

In effect, the Warrant Economics form of market fundamentalism that capitalism has evolved into is meticulously concealed by the PPA elites: corporate excesses are pardoned; the ability of the unchecked rampant financial system to generate systemic crises (explored by Minsky, 1977, through his financial instability hypothesis), and the ensuing mismatch between public risk and private reward are excised from their analyses; and the social fabric torn asunder is justified by lauding greed as an economic virtue.

In this faculty of thought, we argued that the ever unfolding crisis is not an unpredictable, low probability event but, rather, the "natural" symptom of the hubristic and intrinsically unstable market system of Warrant Economics destined to be exposed and challenged.

The tremors of the Great Recession preclude us from keep having our 'Eyes Wide Shut' to the fact that "Among us today a concentration of private power without equal 
in history is growing. This concentration is seriously impairing the economic effectiveness of private enterprise as a way of providing employment for labor and capital and as a way of assuring a more equitable distribution of income and earnings among the people of the nation as a whole." Remarkably, this was the message to the US Congress on the Concentration of Economic Power by Franklin D. Roosevelt in 1938, April 29. ${ }^{37}$

In the context of our work it is illuminating to read, four years prior to the above message: "Capitalism seems to retain remarkable vitality; but it can hardly survive the political rigors of another depression; and banking, with the able assistance of monopoly, seems certain to give us both bigger and better depressions hereafter-unless the state does reassume and discharge with some wisdom its responsibility for controlling the circulating medium" (Simons, [1934]1948, p.56). After more than seventy years from Roosevelt's and Simon's misgivings, the neoliberal dogma having bulldozed liberal economic thinking and seized its academic estate has developed a strong grasp in policy making.

Income distribution and inequality have been sidelined in mainstream economic theorising and policy design under the auspices of the meritocratic position of a one-to-one relationship between wages and productivity in the long run. Snapshot inequality is cursory received by the custodians of our dysfunctional market system under the illusive proviso that there is social mobility within lifetimes and across generations; after all capitalism has never been an equitable system the argument goes. Warrant Economics unveils the fallacy of the productivity-reward dictum, and lays the groundwork for comprehending the unprecedented (in post-WWII democratic states) concentration of the "wealth of nations' in the top 1\%. Concurrently, with the uncovering of the function of Call-Put synergies the adage 'living above our means', used by administrations (either preemptively or trapped in the sovereign debt crisis) to justify the draconian austerity measures and assault on the welfare system and indirect wage, becomes the insult after the injury to the bottom 99 percent of their citizens.

Addressing the malaises of capitalism of the last 30 years one has to confront the inner foundations and representations of the twisted market system that we perused in our work and, ideally abrogate, realistically mitigate, the Call-Put distortions that have become the "thing-in-itself" of the modern, knowledgeable society.

As the crisis intensifies and public outrage gathers momentum it is being argued by many (e.g. Stiglitz, 2010) that a new economic paradigm is needed. For Kuhn (1962), crisis, the common awareness that something has gone wrong, is the usual prelude for a paradigm shift. A new economic paradigm will develop as long as one alienates herself from the rhetoric of the incumbent and understands how the economic system is functioning in its current form. We rest our case with the conviction that the thesis on Warrant Economics serves this noble purpose.

\footnotetext{
${ }^{37}$ http://www.informationclearinghouse.info/article12058.htm
} 


\section{References}

[1] Alvaredo, F., Atkinson A. B., Piketty T., and E. Saez (2011). The World Top Incomes Database: http://g-mond.parisschoolofeconomics.eu/topincomes, 23/11/2011.

[2] Aron-Dine, A., and I. Shapiro (2007). "Share of National Income Going to Wages and Salaries at Record Low in 2006", Center on Budget and Policy Priorities, Washington.

[3] Arrow, K. J. (1970). "Political and Economic Evaluation of Social Effects and Externalities", NBER volume: The Analysis of Public Output, 1-30, http://www.nber.org/chapters/c3349.pdf

[4] Arrow, K., and G. Debreu (1954). "Existence of an Equilibrium for a Competitive Economy", Econometrica, 22, 265-290.

[5] Backhouse, R. E. (2002). "Don Patinkin: Interpreter of the Keynesian Revolution," European Journal of the History of Economic Thought, 9, 186-204.

[6] Baran, P. A., and P. M. Sweezy (1966). "Monopoly Capital", Monthly Review Press, New York.

[7] Barro, R. J. (1974). "Are Government Bonds Net Wealth?", Journal of Political Economy, 82, 1095-1117.

[8] Barro, R. J. (1976). "Reply to Feldstein and Buchanan", Journal of Political Economy, 84, 343-350.

[9] Biewen, M., and A. Juhasz (2010). "Understanding Rising Income Inequality in Germany", IZA Discussion Paper 5062, Bonn.

[10] BIS (2009). "Household debt: implications for monetary policy and financial stability", Bank for International Settlements, BIS Papers No 46.

[11] Blaug, M. (1992). "The Methodology of Economics or How Economists Explain", Cambridge University Press, Second Edition.

[12] Bowles, S., and H. Gintis (2000). "Walrasian Economics in Retrospect", The Quarterly Journal of Economics, November, 1411-1439.

[13] Braudel, F. (1979). "Civilization and Capitalism, 15th-18th Century", Harper \& Row, New York.

[14] Brecht, M., Tober S., van Treeck T., and A. Truger (2010). "Squaring the circle in Euroland? Some remarks on the Stability and Convergence Programmes 2010-2013", Macroeconomic Policy Institute (IMK) Working Paper 3/2010, Düsseldorf.

[15] Chamley, C., and B. Pinto (2011). "Why Official Bailouts Tend Not to Work: An Example Motivated by Greece 2010", Economists' Voice, vol. 8, iss. 1, article 3.

[16] Chari, V. V., and P. J. Kehoe (2008). "The State of Macroeconomics", Journal of Economic Perspectives (Comments), 22, 243-249.

[17] Chari, V. V., Kehoe P. J., and E. R. McGrattan (2009). "New Keynesian Models: Not Yet Useful for Policy Analysis", American Economic Journal: Macroeconomics, 1, 242-266.

[18] Doidge, N. (2007). "The Brain that Changes Itself", Penguin Books, London. 
[19] Edlin, A. S., and D. M. Jaffee (2009). "Show me the Money", Economists' Voice, vol. 6, iss. 4, article 8.

[20] Edward, P. (2006). "Examining Inequality: Who Really benefits from Global Growth?", World Development, 34, 1667-1695.

[21] Elmendorf, D. W., and N. G. Mankiw (1998). "Government Debt", NBER Working Paper No. 6470.

[22] Feldstein, M. (1976). "Perceived Wealth in Bonds and Social Security: A Comment", Journal of Political Economy, 84, 331-336.

[23] Felipe, J., and J. S. L. McCombie (2005). "How Sound are the Foundations of the Aggregate Production Function?", Eastern Economic Journal, 31, 467-488.

[24] Gustafsson, B., and B. Jansson (2008). "Top incomes in Sweden over three-quarters of a century: a micro data approach", Cambridge Journal of Economics, 32, 963-976.

[25] Financial Times (2008, February 5). 'Why it is so Hard to Keep the Financial Sector Caged' by Martin Wolf.

[26] Financial Times (2008, October 29). 'Stuck in the Middle' by Edward Luce.

[27] Financial Times (2009, March 3). 'How the competent bankers can be assisted' by John Kay.

[28] Financial Times (2010, February 3). 'Mind the Gap' by Chris Giles.

[29] Financial Times (2010, April 21). 'The challenge of halting the financial doomsday machine' by Martin Wolf.

[30] Financial Times (2010, July 30). 'The crisis of middle-class America' by Edward Luce.

[31] Financial Times (2010, August 19). 'Needed: a new economic paradigm' by Joseph Stiglitz.

[32] Financial Times (2011, May 13). 'Top earners enjoy big pay rises' by Daniel Pimlott.

[33] Financial Times (2011, May 27). 'Drawback with ETFs lies in their advantages' by John Authers.

[34] Financial Times (2011, June 5).'Push-button perils' by Richard Milne, Michael Mackenzie and Nicole Bullock.

[35] Financial Times (2011, June 16).'Britain's curiously continental job market' by Martin Wolf.

[36] Financial Times (2011, November 6). 'MF Global gives the Fed a lesson in to pick its friends' by Mark Williams.

[37] Financial Times (2011, November 11). 'MF Global revives regulatory calls' by Gregory Meyer.

[38] Fisher, F. M. (1969). "The Existence of Aggregate Production Functions", Econometrica, 37, 553557.

[39] Foster J. B., McChesney R. W., and R. J. Jonna (2011). "Monopoly and Competition in TwentyFirst Century Capitalism", Monthly Review, 62 (11), 1-23.

[40] Galbraith, J. K. (2004). "The Economics of Innocent Fraud", Allen Lane, Penguin Group. 
[41] Goodfriend, M. and R. G. King (1997). "The new neoclassical synthesis and the role of monetary policy. NBER Macroeconomics Annual, 12, 231-295.

[42] Gorton, G., and K. G. Rouwenhorst (2006). "Facts and Fantasies about Commodity Futures", Financial Analysts Journal, 62, 47-68

[43] Heisenberg, W. ([1971], 1985). "Reminiscences from 1926 and 1927", in Neils Bohr: A Centenary Volume, A. P. French and P. J. Kennedy (Eds), International Commission on Physics Education, Harvard University Press.

[44] Hutchison, T. (2000). "On the Methodology of Economics and the Formalist Revolution", Edward Elgar, Cheltenham UK.

[45] Kalecki, M. ([1952]2009). "Theory of Economic Dynamics", Monthly Review Press Classics, Allen \& Unwin, New York.

[46] Keynes, J. M. (1936). "The General Theory of Employment Interest and Money", MacMillan Cambridge University Press, Reprinted 1989.

[47] Kregel, J. (2010). "Is Reregulation of the Financial System an Oxymoron?", Levy Economics Institute of Bard College WP 585.

[48] Krugman, P. (2008). "The Return of Depression Economics and the Crisis of 2008", Penguin Books.

[49] Krugman, P. (2009). 'How Did Economists Get It So Wrong?' New York Times, September 6.

[50] Krugman, P. (2010). 'The cruel bonds cult', The Guardian, 20 August. Copyright: New York Times.

[51] Kuhn, T. S. (1962). "The Structure of Scientific Revolutions", Third Edition, The University of Chicago Press.

[52] Lakatos, I. ([1978]1999). "The methodology of scientific research programmes", J. Worrall and G. Currie (Eds), Philosophical Papers Volume 1, Cambridge University Press.

[53] Lasswell, H., and A. Kaplan (1950). "Power and Society: A Framework for Political Inquiry", Yale University Press, New Haven and London.

[54] Lipsey, R., and K. Lancaster (1956-1957). "The General Theory of the Second Best", Review of Economic Studies, 24, 11-32.

[55] Leijonhufvud, A. (1968). "On Keynesian Economics and the Economics of Keynes: A Study in Monetary Theory", Oxford University Press.

[56] Mandeville, B. ([1728], 2010). "The Fable of the Bees: Or Private Vices, Public Benefits", Kessinger Publishing's Rare Reprints, www.kessinger.net

[57] Mayr, E. (2001). "What Evolution is", Basic Books.

[58] McCloskey, D. (1983). The Rhetoric of Economics", Journal of Economic Literature, 21, 481-517. 
[59] Milonakis, D., and Fine B. (2009). From Political Economy to Economics", Routledge, London and New York.

[60] Minsky, H. P. (1977). "The Financial Instability Hypothesis: An Interpretation of Keynes and an Alternative to "Standard" Theory", Nebraska Journal of Economics and Business, 16, 5-16.

[61] Piketty, T., and E. Saez (2006). The Evolution of Top Incomes: A Historical and International Perspective", The American Economic Review, 96, 200-205.

[62] Ricardo, D. ([1846]2009). "Essay on the Funding System" in "The Works of David Ricardo", J. R. MCullogh (Ed)., BiblioLife LLC.

[63] Robbins, L. ([1932]2007). "An Essay on the Nature and Significance of Economic Science", The Mises Institute, Alabama.

[64] Robbins (1971). "Autobiography of An Economist", MacMillan, London.

[65] Robinson, J. (1978). "Contributions to Modern Economics", Basil Blackwell, Oxford.

[66] Saez, E. (2010). "Striking it Richer: The Evolution of Top Incomes in the United States", mimeo: http://elsa.berkeley.edu/ saez/saez-UStopincomes-2008.pdf

[67] Seater, J. J. (1993). "Ricardian Equivalence", Journal of Economic Literature, XXXI, 143-190.

[68] Shubik, M. (1970). "A curmudgeon's guide to microeconomics", Journal of Economic Literature, 8, 405-434.

[69] Simons, H. C. ([1934]1948). "Economic Policy for a Free Society", Allen \& Unwin, London.

[70] Smith, R. P. (2009). "Real-Financial Interactions in Macro-Finance Models", Quantitative and Qualitative Analysis in Social Sciences, 3(1), 1-20, http://www.qass.org.uk/pastissuesV3I1Y09.htm

[71] Solow, R. (1986). "Economics: Is Something Missing?", in Economic History and the Modern Economist, pp. 21-29, W. N. Parker (Ed), Basil Blackwell, Oxford, UK.

[72] Solow, R. (2008). "The State of Macroeconomics", Journal of Economic Perspectives (Comments), $22,243-249$.

[73] Steindl J. ([1952]1976). "Maturity and Stagnation in American Capitalism", Monthly Review Press, New York and London.

[74] Steinhardt, P. J., and N. Turok (2007). "Endless Universe", Weidenfeld \& Nicolson, Orion Publishing Group Ltd, London.

[75] Stigler, G. J. (1974). "Henry Calvert Simons", Journal of Law $\mathcal{E}$ Economics, 17, 1-5, University of Chicago Press.

[76] Stiglitz, J. E. (2003). "The Roaring Nineties", Penguin Books.

[77] Stiglitz, J. E. (2009). "America's Socialism for the Rich", The Economists' Voice, vol. 6, iss. 6, article 5 . 
[78] Stiglitz, J. E. (2010). 'Needed: a new economic paradigm', Financial Times, 19 August.

[79] Stockhammer, E. (2004). "Financialisation and the Slowdown of Accumulation", Cambridge Journal of Economics, 28, 719-741.

[80] The Guardian (2011, 29 June). 'How QE delivered a triple whammy of profits to the banks' byTom Bawden.

[81] The Economist (2006, June 17th). 'Inequality in America', Special report.

[82] The High Pay Commission (2011). 'More for Less: what has happened to pay at the top and does it matter?' Interim report of the High Pay Commission May 2011, www.highpaycommission.co.uk

[83] Van Horn, R. (2011). "Chicago's Shifting Attitude Toward Concentrations of Business Power (19341962)", Seattle University Law Review, 34, 1527-1544.

[84] Wallerstein, I. (1991). "Braudel on Capitalism, or Everything Upside Down", Journal of Modern History, 63, 354-361.

[85] WDM (2010). World Development Movement report: 'The great hunger lottery' www.wdm.org.uk/food-speculation/great-hunger-lottery

[86] Wolff, E. N., and A. Zacharias (2006). "Wealth and Income Inequality: Who's at the Top of the Economic Ladder?", The Levy Economics Institute of Bard College, LIMEW Report, December 2006.

[87] Woodford, M. (2009). "Convergence in Macroeconomics: Elements of the New Synthesis", American Economic Journal: Macroeconomics, 1, 267-279 